\title{
Genomic markers of ovarian adenocarcinoma and its relevancy to the effectiveness of chemotherapy
}

\author{
MONIKA ENGLERT-GOLON ${ }^{1 *}$, BARTOSZ BURCHARDT $^{1,2^{*}}$, BARTLOMIEJ BUDNY $^{3}$, SZYMON DĘBICKI $^{3}$, \\ BLANKA MAJCHRZYCKA ${ }^{3}$, ELZBIETA WROTKOWSKA ${ }^{3}$, PIOTR JASINSSKI ${ }^{4}$, KATARZYNA ZIEMNICKA $^{3}$, \\ RADOSŁAW SŁOPIEN' ${ }^{5}$, MAREK RUCHAŁA ${ }^{3}$ and STEFAN SAJDAK ${ }^{1}$ \\ ${ }^{1}$ Surgical Gynecology Clinic of The Gynecological and Obstetrics Clinical Hospital; ${ }^{2}$ Department of Forensic Sciences; \\ ${ }^{3}$ Department of Endocrinology, Metabolism and Internal Diseases; ${ }^{4}$ Gynecological and Obstetrics Clinical Hospital; \\ ${ }^{5}$ Department of Gynecological Endocrinology, Poznan University of Medical Sciences, 60-535 Poznan, Poland
}

Received November 22, 2016; Accepted April 13, 2017

DOI: $10.3892 / \mathrm{ol} .2017 .6590$

\begin{abstract}
Ovarian cancer is the eighth most common cancer and the seventh highest cause of cancer-associated mortality in women worldwide. It is the second highest cause of mortality among female reproductive malignancies. The current standard first-line treatment for advanced ovarian cancer includes a combination of surgical debulking and standard systemic platinum-based chemotherapy with carboplatin and paclitaxel. Although a deeper understanding of this disease has been attained, relapse occurs in $70 \%$ of patients 18 months subsequent to the first-line treatment. Therefore, it is crucial to develop a novel drug that effectively affects ovarian cancer, particularly tumors that are resistant to current chemotherapy. The aim of the present study was to identify genes whose expression may be used to predict survival time or prognosis in ovarian cancer patients treated with chemotherapy. Gene or protein expression is an important issue in chemoresistance and survival prediction in ovarian cancer. In the present study, the research group consisted of patients treated at the Surgical Clinic of the Gynecology and Obstetrics Gynecological Clinical Hospital, Poznan University of Medical Sciences (Poznan, Poland) between May 2006 and November 2014. Additional eligibility criteria were a similar severity (International Federation of Gynecolgy and Obstetrics stage III) at the time of diagnosis, treatment undertaken in accordance with the same schedule, and an extremely good response to
\end{abstract}

Correspondence to: Professor Stefan Sajdak or Mr. Bartosz Burchardt, Surgical Gynecology Clinic of The Gynecological and Obstetrics Clinical Hospital, Poznan University of Medical Sciences, Ul. Polna 33, 60-535 Poznan, Poland

E-mail:kgo.ela@wp.pl

E-mail: bartosz.jan.burchardt@gmail.com

*Contributed equally

Key words: ovarian adenocarcinoma, point gene mutations, efficacy of the treatment, microarrays treatment or a lack of response to treatment. The performance of the OncoScan ${ }^{\circledR}$ assay was evaluated by running the assay on samples obtained from the four patients and by following the recommended protocol outlined in the OncoScan assay manual. The genomic screening using Affymetrix OncoScan Arrays resulted in the identification of large genomic rearrangements across all cancer tissues. In general, chromosome number changes were detected in all examined tissues. The OncoScan arrays enabled the identification of $\sim 100$ common somatic mutations. Chemotherapy response in ovarian cancer is extremely complex and challenging to study. The present study identified specific genetic alterations associated with ovarian cancer, but not with response for treatment.

\section{Introduction}

Ovarian cancer is the eighth most common cancer and the seventh leading cause of cancer-associated mortality in women worldwide. It is the second highest cause of mortality among female reproductive malignancies and accounts for 140,200 mortalities each year. The estimated incidence and number of mortalities in the USA from ovarian cancer is 21,980 cases and 14,270 mortalities, respectively, for 2014 (1,2). Ovarian cancer is the fourth most common malignancy in women and is the leading cause of gynecological cancer-associated mortality. Poland is one of the countries with high morbidity rates for ovarian carcinoma. Epidemiological data show steady rise of ovarian cancer incidence. Due to late-onset symptoms, ovarian cancer is mainly diagnosed in an advanced stage. In total, $60-70 \%$ of patients present with stage III or IV disease and are therefore associated with poor survival. The International Federation of Gynecology and Obstetrics (FIGO) staging classification in ovarian cancer has an independent prognostic role. The major role of the staging system is not only to provide universal terminology that may be used in different oncological hospitals worldwide, but it also informs us about the prognosis and outcome prediction subsequent to specific treatment. The majority of ovarian cancer patients are diagnosed with late-stage disease as the asymptomatic progression is poorly understood, and an efficient screening strategy is not presently available (3-5). The 
current standard first-line treatment for advanced ovarian cancer includes a combination of surgical debunking and standard systemic platinum-based chemotherapy with carboplatin and paclitaxel $(6,7)$. This standard treatment results in $>80 \%$ response rates and $40-60 \%$ complete responses; however, the majority of patients with advanced disease (stages III-IV) will eventually relapse, even with initial disease response. Improvement in survival has also been poor in ovarian cancer. Gene expression-based tools for the prediction of patient prognosis subsequent to surgery or chemotherapy are currently available for certain cancers. The prediction of cancer prognosis using molecular signatures is a popular research field, within which a wide variety of approaches have been considered (7). Popular RNA or protein expression measurement techniques include cDNA hybridization microarrays, end-point and quantitative reverse transcription polymerase chain reaction (PCR), and immunohistochemistry approaches (8). Although a deeper understanding of this disease has been attained, relapse continues to occur in $70 \%$ of patients 18 months following the first-line treatment. Therefore, it is crucial to develop a novel drug that effectively impacts on ovarian cancer, particularly one that is resistant to current chemotherapy. The 5 -year survival rate of ovarian cancer patients with stage I is $92 \%$. However, patients diagnosed in the late stage have poor prognosis, with a 5-year survival rate of only $19 \%$ for stage IV patients. The median progression-free survival time ranges between 16 and 21 months, and the median overall survival time ranges between 24 and 60 months $(9,10)$. Subsequent to repeated cycles of chemotherapy, recurrent ovarian cancer eventually develops resistance to numerous available cytotoxic agents. As a result, studies into the mechanisms of drug-resistance, biomarkers for drug resistance, and the development of new-targeted therapies have been the subject of numerous ovarian cancer studies (11). Although patients receiving standard therapy, including surgical cytoreduction and platinum-based combination chemotherapies, may have an initial favorable response, the majority of patients experience relapse within 5 years (12). Consequently, there is an urgent requirement for novel treatments for this deadly disease.

The aim of the present study was to identify genes of which the expression may be used to predict survival time or prognosis in ovarian cancer patients treated witch chemotherapy. As aforementioned, the presence of resistance to the chemotherapy agent administered dramatically affects the survival of a patient. It is therefore reasonable to expect the gene signatures identified to include genes responsible for chemoresistance, which will affect the mechanism of action of the drug. Gene or protein expression is an important issue of chemoresistance and survival prediction in ovarian cancer. The concept of identifying gene signatures is popular, but requires careful handling to extract the information required for this to be successful. There are certain previous studies that investigated the differing response of different types of ovarian cancer to chemotherapy (13). Identification of biomarkers that can reliably predict drug sensitivity and resistance is extremely important.

\section{Materials and methods}

In the present study, the research group consisted of patients treated at the Surgical Clinic of the Gynecology and Obstetrics
Gynecological Clinical Hospital, Poznan University of Medical Sciences (Poznan, Poland) between May 2006 and November 2014. Of the 2,000 patients, four who suffered from ovarian serum carcinoma were chosen. Additional eligibility criteria were a similar severity (FIGO stage IIIC) at the time of diagnosis, treatment undertaken in accordance with the same schedule, and an extremely good response to treatment or a lack of response to treatment. Finally, two patients who had an exceptionally good response to treatment and two patients who did not respond to treatment were selected. A detailed description of the therapeutic effects of the patients enrolled in the present study is subsequently reported. Informed consent was obtained from all patients, and ethical approval was provided by the Bioethics Committee of Poznan University of Medical Sciences.

The tissue samples were collected from neoplastic lesions removed during surgery prior to starting drug therapy. The tissues were stored in paraffin blocks.

\section{Case reports}

Case 1. Patient 1 (48 years of age) was classified as having a good response to treatment. The patient was referred from a gynecological ward of Gniezno County Hospital (Gniezo, Poland) in October 2007 with a suspected neoplastic process that extended from the ovary, for treatment at the. Surgical Gynecology Clinic of the Gynecological and Obstetrics Clinical Hospital (Poznan, Poland). On admission, vaginal and transabdominal ultrasounds were performed, which showed conglomerate tumors occupying the pelvis. This ovarian tumor had the following dimensions, $7 \times 8$ and $6 \times 5.9 \mathrm{~cm}$ infiltrated the large intestine (descending colon and anus) and bladder. The level of the marker cancer antigen (CA) 125 was $207 \mathrm{IU} / \mathrm{ml}$ in the blood (normal reference values are $<35 \mathrm{IU} \mathrm{ml}$ ). Subsequent to preparation, partial excision of the pelvic tumor, with reconstruction of the walls of the bladder and anastomosis of the proximal descending colon and the rectum was performed. Unfortunately, due to infiltration of the tumor into the left iliac vessels, the whole tumor was not removed Subsequent to a period of recuperation in November 2007, treatment was commenced with first-line chemotherapy, consisting of paclitaxel and cisplatin (intravenous infusion of paclitaxel $175 \mathrm{mg} / \mathrm{m}^{2}$ and $75 \mathrm{mg} / \mathrm{m}^{2}$ cisplatin per cycle lasting $3 \mathrm{~h}$ with 3 weeks break between chemotherapy cycles) which lasted continuously until February 2008. At the start of this stage of treatment, a lesion in the vicinity of the left iliac vessels were visible on transvaginal ultrasound, $1.0 \times 0.7 \mathrm{~cm}$ in size, while the CA125 level was $50 \mathrm{IU} / \mathrm{ml}$ in the blood. Subsequent to a cycle of paclitaxel and cisplatin chemotherapy (intravenous infusion of paclitaxel $175 \mathrm{mg} / \mathrm{m}^{2}$ and $75 \mathrm{mg} / \mathrm{m}^{2}$ cisplatin per cycle lasting $3 \mathrm{~h}$ with 3 weeks break between chemotherapy cycles.), this lesion was invisible and the CA125 level was $13 \mathrm{IU} / \mathrm{ml}$ in the blood. At a follow-up in late April 2008, ultrasound examinations found recurrence in the vicinity of the left iliac vessels, with a dimension of $4 \times 4 \times 5 \mathrm{~cm}$ and the patient was admitted to the oncology clinic of the Gynecology and Obstetrics Gynecological Clinical Hospital (Poznan, Poland). It was decided to perform surgery to remove the lesion. Considering the high infiltration of the left iliac vessels and subsequent to consultation with a vascular surgeon, the lesion was not entirely removed, leaving a fragment of a tumor measuring 
$\sim 0.5 \times 0.5 \mathrm{~cm}$ around the left common iliac artery. The next stage of treatment was second-line chemotherapy consisting of cyclophosphamide and cisplatin (intravenous infusion of cyclophosphamide $750 \mathrm{mg} / \mathrm{m}^{2}$ and $75 \mathrm{mg} / \mathrm{m}^{2}$ cisplatin per cycle lasting $3 \mathrm{~h}$ with 3 weeks break between chemotherapy cycles, which started at the end of May 2008. However, subsequent to 2 cycles of chemotherapy, the patient had a strong anaphylactic reaction to the chemotherapy, which resulted in a change to topotecan (to $1.5 \mathrm{mg} / \mathrm{m}^{2}$ for 5 days every 3 weeks). The level of CA125 (7 IU/ml) in the blood had decreased to $3 \mathrm{IU} / \mathrm{ml}$ at the end of therapy, the baseline was following completion of the topotecan treatment. Chemotherapy was completed in late October/November 2008, with the ultrasound also revealing no pelvic lesions; it was decided to continue treatment on an outpatient basis, with one follow-up every 3 weeks. During a follow-up in late December 2008, a recurrence $7 \times 5 \times 5 \mathrm{~cm}$ in size was observed around the left iliac vessels. In addition, the patient experienced deterioration in general condition, including a lack of appetite, weakness and weight loss $(12 \mathrm{~kg}$ within 7 weeks). At the request of the patient, further treatment was not commenced, and it was decided in consultation with the patient for palliative care to be administered at their place of residence. The patient succumbed in mid-January 2009. At the request of the family, no autopsy was performed.

Case 2. Patient 2 (50 years of age) was classified as having a good response to treatment. The patient presented to the gynecological clinic of the local hospital in Kościan (Kościan County Hospital) in February 2009 subsequent to the accidental detection of a polycystic solid tumor in the pelvic cavity, posterior to the uterus, during abdominal ultrasound. The patient was urgently admitted to the Surgical Gynecology Clinic of the Gynecological and Obstetrics Clinical Hospital in March 2009 and a transvaginal ultrasonography revealed a tumor $9 \times 5 \times 5 \mathrm{~cm}$ in size that was in contact with the ascending colon and bladder. The patient reported a history of partial hysterectomy in July 2007. The CA125 level in the blood was $175 \mathrm{IU} / \mathrm{ml}$. Subsequent to preparation, surgery was performed to remove the lesions originating from the right ovary, with the macroscopically unchanged left ovary. Following a period of recovery, first-line chemotherapy consisting of paclitaxel and carboplatin (6 cycles intravenous infusion of paclitaxel, $175 \mathrm{mg} / \mathrm{m}^{2}$ lasting $3 \mathrm{~h}$, followed by $400 \mathrm{mg} / \mathrm{m}^{2}$ carboplatin per cycle, with 3 weeks between cycles.) was commenced in mid-April 2009. Throughout the administration of chemotherapy, there were no lesions in the pelvic cavity and the level of the marker CA125 in the blood dropped between $40 \mathrm{IU} / \mathrm{ml}$ at the start of chemotherapy and $13 \mathrm{IU} / \mathrm{ml}$ at its completion. In the period between September 2009 and February 2013, the patient was admitted to the Surgical Gynecology Clinic of the Gynecological and Obstetrics Clinical Hospital. In March 2013 during a routine follow-up, a pelvic lesion 7x10x5 cm in size was identified in the right ovary. The patient was admitted to the clinic in order to perform surgery to remove the lesion. The CA125 level was $51 \mathrm{IU} / \mathrm{ml}$. Underwent radical changes and the removal of deciding to start at the beginning of March 2013 chemotherapy (3 cycles of intravenous infusion of paclitaxel $175 \mathrm{mg} / \mathrm{m}^{2}$ and carboplatin $400 \mathrm{mg} / \mathrm{m}^{2}$ per cycle lasting $3 \mathrm{~h}$ with 3 weeks break between chemotherapy cycles). During the third course of chemotherapy, the patient developed an adverse reaction to carboplatin (palmar-plantar erythrodysesthesia) that resulted in carboplatin being replaced by cisplatin ( 3 cycles of intravenous infusion of $75 \mathrm{mg} / \mathrm{m}^{2} \mathrm{cispl}-$ atin per cycle; 3 weeks break between chemotherapy cycles). Chemotherapy was completed in August 2014, and the patient was referred for follow-up. The last follow-up took place in October 2014. No lesions were detected in the pelvic cavity and the level of CA125 in the blood was $10 \mathrm{IU} / \mathrm{ml}$. The patient succumbed to cardiogenic shock in mid-December 2014. At the request of the family, no autopsy was performed.

Case 3. Patient 3 (49 years of age) was classified as being unresponsive to treatment. In October 2009, the patient was admitted to the Department of Gynecology, Konin district hospital (Konin, Poland) due to a pelvic tumor. On admission to the Surgical Gynecology Clinic of the Gynecological and Obstetrics Clinical Hospital, transvaginal ultrasonography revealed a solid lesion with multiple compartments that filled the entire pelvis, with smaller dimensions totaling $12 \times 10 \times 17 \mathrm{~cm}$. The tumor infiltrated the bladder and bowel. There was no point in time at which the point where the cancer lesion came from could be reached. The level of CA125 in the blood was $156 \mathrm{IU} / \mathrm{ml}$. Subsequent to preparation, non-radical resection of the tumor was performed, including the uterus and ovaries, a fragment of the wall of the bladder and a section of the descending colon. Among the surgically reconstructed section, colon end-to-side colon anastomosis was performed. However, a small residual section infiltrating the jejunum was left. Following a period of recuperation in mid-November 2009, first-line chemotherapy consisting of paclitaxel and carboplatin $\left(6\right.$ cycles of intravenous infusion of paclitaxel $175 \mathrm{mg} / \mathrm{m}^{2}$ and $400 \mathrm{mg} / \mathrm{m}^{2}$ carboplatin per cycle lasting $3 \mathrm{~h}$ with 3 weeks break between chemotherapy cycles) was commenced. During the examination prior to the first treatment cycle, lesions were detected in the pelvis and the blood CA125 level was $21 \mathrm{IU} / \mathrm{ml}$. Following 3 cycles of chemotherapy, pelvic free fluid appeared, and the amount of fluid increased in the following cycle. Prior to the last cycle of (February 2010) chemotherapy, a lesion that involved the bladder wall, $2 \times 2 \times 3 \mathrm{~cm}$ in size, was observed during the ultrasound. Due to the poor condition and increasing shortness of breath of the patient, the peritoneal cavity was punctured, and over 3 days, 51 of fluid were removed. Subsequent to another week of hospitalization and further deterioration in the general condition of the patient, further treatment was not administered at the patient's request, and the patient was discharged. Palliative care was administered between discharge (beginning of April 2010) and early June 2010, when the patient succumbed to ovarian cancer.

Case 4. Patient 4 (49 years of age) was classified as being unresponsive to treatment. In November 2010, the patient was referred to Surgical Gynecology Clinic of the Gynecological and Obstetrics Clinical Hospital by a physician, due to the detection of bilateral ovarian tumors by screening ultrasound. On admission, transvaginal ultrasound was performed, and a solid tumor with central vascularization, measuring $2 \times 1 \times 2 \mathrm{~cm}$, was identified in the left ovary, and a multi-element solid tumor located centrally with peripheral vasculature, measuring $4 \times 3 \times 5 \mathrm{~cm}$, was identified in the right ovary. The level of CA125 in the blood was $410 \mathrm{IU} / \mathrm{ml}$. A radical hysterectomy with removal of the two ovaries, tumors and lymph nodes was performed. Following a period of recovery, first-line chemotherapy consisting of carboplatin and paclitaxel (6 cycles of 
intravenous infusion of paclitaxel $175 \mathrm{mg} / \mathrm{m}^{2}$ and $400 \mathrm{mg} / \mathrm{m}^{2}$ carboplatin per cycle lasting $3 \mathrm{~h}$ with 3 weeks break between chemotherapy cycles) was commenced in mid-December 2010. At the starting of chemotherapy, the CA125 level in the blood was $47 \mathrm{IU} / \mathrm{ml}$, and subsequent to the completion of chemotherapy, it was $46 \mathrm{IU} / \mathrm{ml}$. In May 2011, subsequent to finishing the whole course of treatment, the patient was referred to the Surgical Gynecology Clinic of the Gynecological and Obstetrics Clinical Hospital for follow-up. In June 2011, ultrasound examinations observed a lesion $2 \times 2 \times 0.5 \mathrm{~cm}$ in size, which gradually widened (between December 2010 and May 2011) to $7 \times 10 \times 6 \mathrm{~cm}$ in size. There was also an increase in the level of CA125 in the blood to $211 \mathrm{IU} / \mathrm{ml}$ in February 2013. The patient did not agree to the proposed hospitalizations and surgical procedures. In February 2013, a painful lump 2x2 cm in size was observed in the postoperative scar. Subsequent to obtaining consent from the patient to perform the surgery, a localized lesion in the vagina was removed. In addition, a partly invasive bladder recurrence was removed by local resection of the bladder wall, and a tumor located in the subcutaneous tissue, which was identified as metastasis, was also removed. Following a period of recuperation, second-line chemotherapy consisting of paclitaxel and carboplatin (6 cycles of intravenous infusion of paclitaxel $175 \mathrm{mg} / \mathrm{m}^{2}$ and $400 \mathrm{mg} / \mathrm{m}^{2}$ carboplatin per cycle lasting $3 \mathrm{~h}$ with 3 weeks break between chemotherapy cycles) was commenced in April 2013. Prior to the fourth cycle of chemotherapy, transvaginal ultrasound was performed, and identified a localized bladder lesion $2 \times 1 \times 1 \mathrm{~cm}$ in size, which, despite treatment, gradually increased in size over 3 cycles (13 weeks). Subsequent to completion of chemotherapy treatment for the localized lesion $(4 \times 4 \times 3 \mathrm{~cm}$ above the vagina) and the level of CA125 in the blood increased from the initial $13 \mathrm{IU} / \mathrm{ml}$ to $97 \mathrm{IU} / \mathrm{ml}$ subsequent to treatment. In April 2014, the patient refused to consent to the subsequent chemotherapy and self-discharged. In December 2014, the patient was presented again to the Surgical Gynecology Clinic of the Gynecological and Obstetrics Clinical Hospital with weight loss and weakness and was immediately admitted for treatment. Subsequent to improvement of blood morphology, renal function and the general condition of the patient, the proposed chemotherapy regimen Caelyx (doxorubicin) (6 cycles of $50 \mathrm{mg} / \mathrm{m}^{2}$ doxorubicin per cycle, with 3 weeks between chemotherapy cycles) was administered. In total, six cycles of chemotherapy were administered, which did not stop the growth of the localized lesions in the pelvic cavity. At the end of administrations, the dimensions were $7 \times 5 \times 5 \mathrm{~cm}$ and CA125 from level had increased from the original $136 \mathrm{IU} / \mathrm{ml}$ to 192 IU/ml. In May 2015, chemotherapy was again attempted, with the fourth-line chemotherapy consisting of paclitaxel and carboplatin (6 cycles of intravenous infusion of paclitaxel $175 \mathrm{mg} / \mathrm{m}^{2}$ and $400 \mathrm{mg} / \mathrm{m}^{2}$ carboplatin per cycle lasting $3 \mathrm{~h}$ with 3 weeks break between chemotherapy cycles), which was stopped after 3 courses due to the absence of treatment effects, and the request of the patient to be discharged and discontinue treatment. During the last follow-up, the lesion was 10x9x8 cm in size and the blood CA125 level was $625 \mathrm{IU} / \mathrm{ml}$. The patient succumbed to ovarian cancer in late November 2015.

Genetic examination. The proceeding of a genetic examination was performed as previously described (14). Four formalin-fixed paraffin-embedded (FFPE) ovarian carcinoma tissue samples were obtained from the Cancer Pathology Department at Poznan University of Medical Sciences. The FFPE blocks were no older than 5 years.

In order to obtain a high content of cancer cells for DNA extraction, 5-10 sections (5- $\mu \mathrm{m}$ thick) were cut from each paraffin block, and a set of slides was prepared. One slide per patient was then stained routinely with hematoxylin and eosin to identify regions containing a high concentration of cancer cells. Based on this estimation, regions of interest were dissected from the unstained slides. The dissected cells were then put into a 1.5 Eppendorf tube and DNA was extracted using QIAamp DNA FFPE Tissue kit (Qiagen $\mathrm{GmbH}$, Hilden, Germany), according to the manufacturer's protocol. Following the extraction, DNA was inspected using NanoDrop spectrophotometer (NanoDrop; Thermo Fisher Scientific, Inc.) and the Qubit 2.0, Quant-iT ${ }^{\mathrm{TM}}$ PicoGreen $^{\circledR}$ dsDNA Assay kit (Thermo Fisher Scientific, Inc.). A final concentration of $12 \mathrm{ng} / \mu \mathrm{l}$ DNA in Tris-EDTA buffer (10 mM Tris-HCl, $0.1 \mathrm{mM}$ disodium EDTA, pH 8) was than utilized for the OncoScan ${ }^{\circledR}$ assay (Affymetrix, Inc., Santa Clara, CA, USA). In total, $80 \mathrm{ng}$ of DNA (in $6.6 \mu \mathrm{l}$ ) from each sample were processed. The advantage of the OncoScan assay is possibility of simultaneous identification of copy number alterations, loss of heterozygosity (LOH) and somatic mutations (SMs) in a single experiment. This is possibly due to the use of molecular inversion probe (MIP) technology, and capturing >220,000 small nucleotide polymorphism (SNP) genotypes focused on $\sim 900$ cancer locations, distributed across the genome. Another advantage is the ability to identify selected 'hotspot' somatic mutations in nine genes that particularly contribute to the development of various cancers [tumor protein p53, B-Raf proto-oncogene, serine/threonine kinase, KRAS proto-oncogene, GTPase, epidermal growth factor receptor, isocitrate dehydrogenase 1, isocitrate dehydrogenase 2 , phosphatase and tensin homolog, phosphoinositide-3-kinase catalytic subunit $\alpha$ (PIK3CA) and NRAS proto-oncogene, GTPase]. The experimental procedure includes several steps. Probes were added to the sample DNA, and allowed to anneal at $58^{\circ} \mathrm{C}$ overnight (16-18 h) subsequent to an initial denaturation $\left(95^{\circ} \mathrm{C}\right.$ for $\left.5 \mathrm{~min}\right)$. Samples was then split into two separate reactions, and proceeded as follows: dATP (A) and dTTP (T) (A/T) were added to one reaction, and dGTP $(\mathrm{G})$ and dCTP $(\mathrm{C})(\mathrm{G} / \mathrm{C})$ were added to the second in order to conduct gap fill.

Unincorporated and non-circularized MIPs, as well as the remains of the genomic template, were removed by treatment with exonucleases (Affymetrix, Inc.). The circular MIPs that were gap-filled by the A/T or $\mathrm{G} / \mathrm{C}$ nucleotides were cleaved using the HaeIII enzyme, and their linear form was amplified by PCR. Subsequently, the 120-bp PCR product was cut and the smaller (44-bp) fragment containing the specific SNP genotype was subjected for hybridization onto array. Prior to this, samples were mixed with hybridization buffer and injected into the cartridges for $16-18 \mathrm{~h}$ at $49^{\circ} \mathrm{C}$ and $0.013 \mathrm{x} \mathrm{g}$. Following hybridization, cartridges were removed from the oven, and stained using the GeneChip ${ }^{\circledR}$ Fluidics Station 450 (Affymetrix, Inc.), according to the manufacturer's protocol. Subsequent to staining and washing, arrays were scanned in GeneChip Scanner 3000 7G (Affymetrix, Inc.) and the fluorescence of clusters was measured in order to generate a DAT 


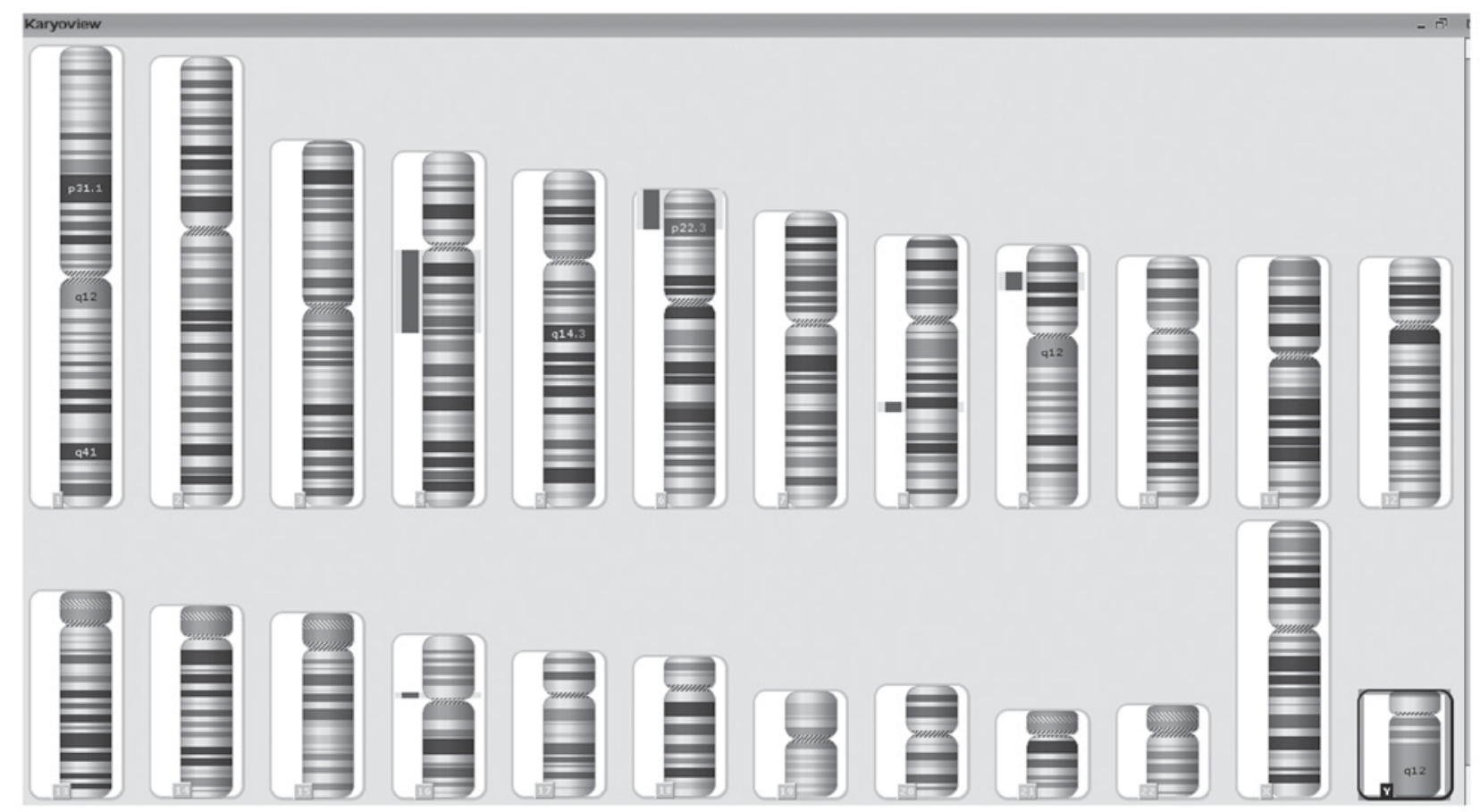

Figure 1. Loss of heterozygosity regions identified in all examined patients. Bars next to the ideogram indicate patients 1-4.

file. Cluster intensities values were automatically calculated using built-in algorithm from DAT files by the Affymetrix GeneChip Command Console software, version 4.0 (Affymetrix, Inc.), and a CEL file was created.

Genomic data analysis. CEL files were processed using OncoScan Console software, version 1.1.034 (Affymetrix, Inc.), to recalculate probe intensities into genomic landscape (OSCHP file) as well as a set of QC metrics (MAPD SNPQC and waviness). For each sample, a profile of copy number alterations was created, expressed by numerical values. The $\mathrm{LOH}$ profile was created for all samples, assuming a high confidence interval of $\geq 3 \mathrm{Mbp}$ (ChAS option). The TuScan algorithm was also used for calculation of ploidy (i.e. 0, 66 or $100 \%)$. Somatic mutations were evaluated and viewed in the ChAS browser (Affymetrix, Inc.). The reliability of calls for SMs depends on the SNPQC parameter, and therefore it was necessary to obtain ndSNPQC $\geq 26$ ('in-bounds') for all tested samples. The OncoScan assays are able to detect mutations by relying on the signal intensity of designed clusters, which is translated into the mutation score. This algorithm recognizes three basic thresholds for calls, termed 'Undetected' for an absence of SMs, and 'Lower confidence' or 'High confidence' for detected changes. In the present study, the default mutation score thresholds supplied in the software were used.

\section{Results}

Genomic studies. Genomic screening using Affymetrix OncoScan arrays resulted in the identification of large genomic rearrangements across all of the cancer tissues. In general, chromosome number changes were detected in all examined tissues. Ploidies were found in three out of four examined samples. Patients 1 and 2 showed incomplete tetraploidy, whereas patient 3 showed incomplete triploidy. Patient 4 showed diploidy, according to the TuScan algorithm, with hypoploidy of chromosomes 13 and 15 . The detailed analysis of regions presenting $\mathrm{LOH}$ resulted in the detection of $152 \mathrm{LOH}$ segments with a minimum $3 \mathrm{Mbp}$ size (Table I). These findings are shown in Fig. 1, and the location of each altered segment was depicted. Subsequently, unique overlapping regions in patients presenting sensitivity for treatment (patients 1 and 2) vs. patients showing resistance (patients 3 and 4) were assessed. For the first cohort, only 5 segments on chromosomes 4, 6, 8, 9 and 16 were identified (Table II; Fig. 2). Within those regions, 10 cancer genes were identified using the COSMIC database. For the second cohort, 20 regions on chromosomes 3-5, 7-9, 10, 11, 14-16 and 19 were identified. Within the selected segments, 45 different cancer genes were found (Table III; Fig. 3). The identified LOH regions for all patients are presented in Fig. 1.

The OncoScan arrays enabled the identification of $\sim 100$ common somatic mutations (Table IV). In the present study, only one mutation was identified, in patient 4 . The mutation affected the PIK3CA gene and lead to a glutamic acid-lysine substitution (p.E542K, c.1624G>A; Cosmic ID, COSM760). Notably, the mutation was found in cancer tissue that was diploid and was showing only a hypoploidy of acrocentric chromosomes (chromosomes 13, 15, 18 and 22).

\section{Discussion}

Ovarian cancer has the highest mortality rate among reproductive cancers and currently ranks as the fifth leading cause of cancer-associated mortalities among women. Despite the improvements achieved in ovarian cancer therapy over previous decades, the overall 5-year survival rate remains 
Table I. LOH regions identified in all examined patients.

\begin{tabular}{|c|c|c|c|c|c|c|c|c|}
\hline No. & Sample & Type & Chrom. & Cytoband & $\begin{array}{c}\text { Genomic } \\
\text { location start }\end{array}$ & $\begin{array}{l}\text { Genomic } \\
\text { location end }\end{array}$ & Size (Kbp) & Gene count \\
\hline 1 & 1_189975.OSCHP & $\mathrm{LOH}$ & 1 & $\mathrm{p} 21.3$ & 115837919 & 96311795 & 19526.124 & 161 \\
\hline 2 & 4_208156_15.OSCHP & $\mathrm{LOH}$ & 1 & p31.3 & 89473522 & 68095206 & 21378.316 & 96 \\
\hline 3 & 3_8376_10.OSCHP & $\mathrm{LOH}$ & 1 & p36.23 & 33275981 & 7892870 & 25383.111 & 392 \\
\hline 4 & 3_8376_10.OSCHP & $\mathrm{LOH}$ & 1 & p36.33 & 4738355 & 754191 & 3984.164 & 97 \\
\hline 5 & 1_189975.OSCHP & $\mathrm{LOH}$ & 1 & p36.33 & 33760197 & 754191 & 33006.006 & 524 \\
\hline 6 & 3_8376_10.OSCHP & $\mathrm{LOH}$ & 1 & $\mathrm{q} 23.3$ & 180377339 & 163377535 & 16999.804 & 144 \\
\hline 7 & 3_8376_10.OSCHP & $\mathrm{LOH}$ & 1 & $\mathrm{q} 31.2$ & 197574134 & 191510124 & 6064.01 & 24 \\
\hline 8 & 2_203344_15.OSCHP & $\mathrm{LOH}$ & 1 & q32.1 & 216605071 & 200649365 & 15955.706 & 180 \\
\hline 9 & 2_203344_15.OSCHP & $\mathrm{LOH}$ & 1 & $\mathrm{q} 43$ & 249212878 & 237257823 & 11955.055 & 102 \\
\hline 10 & 3_8376_10.OSCHP & $\mathrm{LOH}$ & 2 & $\mathrm{p} 21$ & 90245035 & 42993165 & 47251.87 & 302 \\
\hline 11 & 3_8376_10.OSCHP & $\mathrm{LOH}$ & 2 & $\mathrm{p} 25.3$ & 39767074 & 21493 & 39745.581 & 250 \\
\hline 12 & 2_203344_15.OSCHP & $\mathrm{LOH}$ & 2 & q11.2 & 112928815 & 101831270 & 11097.545 & 79 \\
\hline 13 & 1_189975.OSCHP & $\mathrm{LOH}$ & 2 & q13 & 141463604 & 114138191 & 27325.413 & 127 \\
\hline 14 & 2_203344_15.OSCHP & $\mathrm{LOH}$ & 2 & q36.1 & 228157661 & 224463413 & 3694.248 & 18 \\
\hline 15 & 3_8376_10.OSCHP & $\mathrm{LOH}$ & 2 & $\mathrm{q} 36.3$ & 243052331 & 230641762 & 12410.569 & 154 \\
\hline 16 & 2_203344_15.OSCHP & $\mathrm{LOH}$ & 2 & q36.3 & 243052331 & 230903874 & 12148.457 & 152 \\
\hline 17 & 3_8376_10.OSCHP & $\mathrm{LOH}$ & 3 & $\mathrm{p} 21.31$ & 51927415 & 46001062 & 5926.353 & 143 \\
\hline 18 & 4_208156_15.OSCHP & $\mathrm{LOH}$ & 3 & $\mathrm{p} 21.31$ & 53323914 & 50248426 & 3075.488 & 82 \\
\hline 19 & 3_8376_10.OSCHP & $\mathrm{LOH}$ & 3 & $\mathrm{p} 26.3$ & 11539955 & 63410 & 11476.545 & 69 \\
\hline 20 & 4_208156_15.OSCHP & $\mathrm{LOH}$ & 3 & $\mathrm{p} 26.3$ & 49346130 & 63410 & 49282.72 & 368 \\
\hline 21 & 4_208156_15.OSCHP & $\mathrm{LOH}$ & 3 & $\mathrm{q} 22.3$ & 164972840 & 138296967 & 26675.873 & 147 \\
\hline 22 & 3_8376_10.OSCHP & $\mathrm{LOH}$ & 3 & $\mathrm{q} 25.32$ & 168219437 & 157426328 & 10793.109 & 39 \\
\hline 23 & 3_8376_10.OSCHP & $\mathrm{LOH}$ & 3 & $\mathrm{q} 27.1$ & 197852564 & 184416008 & 13436.556 & 129 \\
\hline 24 & 3_8376_10.OSCHP & $\mathrm{LOH}$ & 4 & p15.1 & 35668267 & 29950964 & 5717.303 & 1 \\
\hline 25 & 2_203344_15.OSCHP & $\mathrm{LOH}$ & 4 & p16.3 & 8060637 & 71565 & 7989.072 & 107 \\
\hline 26 & 1_189975.OSCHP & $\mathrm{LOH}$ & 4 & p16.3 & 49092454 & 71565 & 49020.889 & 278 \\
\hline 27 & 1_189975.OSCHP & $\mathrm{LOH}$ & 4 & q11 & 190915650 & 52684890 & 138230.76 & 611 \\
\hline 28 & 2_203344_15.OSCHP & $\mathrm{LOH}$ & 4 & q11 & 190915650 & 52684890 & 138230.76 & 611 \\
\hline 29 & 3_8376_10.OSCHP & $\mathrm{LOH}$ & 4 & $\mathrm{q} 22.3$ & 114068306 & 97748435 & 16319.871 & 90 \\
\hline 30 & 4_208156_15.OSCHP & $\mathrm{LOH}$ & 4 & $\mathrm{q} 24$ & 190915650 & 103271887 & 87643.763 & 337 \\
\hline 31 & 3_8376_10.OSCHP & $\mathrm{LOH}$ & 4 & q26 & 177478156 & 119815943 & 57662.213 & 207 \\
\hline 32 & 4_208156_15.OSCHP & $\mathrm{LOH}$ & 5 & p14.1 & 33066481 & 28142098 & 4924.383 & 12 \\
\hline 33 & 3_8376_10.OSCHP & $\mathrm{LOH}$ & 5 & $\mathrm{q} 11.1$ & 68828372 & 49441965 & 19386.407 & 87 \\
\hline 34 & 4_208156_15.OSCHP & $\mathrm{LOH}$ & 5 & $\mathrm{q} 11.2$ & 68828372 & 51164114 & 17664.258 & 83 \\
\hline 35 & 1_189975.OSCHP & $\mathrm{LOH}$ & 5 & q11.2 & 68828372 & 52864364 & 15964.008 & 77 \\
\hline 36 & 2_203344_15.OSCHP & $\mathrm{LOH}$ & 5 & $\mathrm{q} 11.2$ & 68828372 & 55081693 & 13746.679 & 56 \\
\hline 37 & 3_8376_10.OSCHP & $\mathrm{LOH}$ & 5 & $\mathrm{q} 13.2$ & 90049057 & 70306677 & 19742.38 & 109 \\
\hline 38 & 2_203344_15.OSCHP & $\mathrm{LOH}$ & 5 & $\mathrm{q} 13.2$ & 119919958 & 70306677 & 49613.281 & 206 \\
\hline 39 & 1_189975.OSCHP & $\mathrm{LOH}$ & 5 & $\mathrm{q} 13.2$ & 180698312 & 70306677 & 110391.635 & 749 \\
\hline 40 & 4_208156_15.OSCHP & $\mathrm{LOH}$ & 5 & $\mathrm{q} 13.2$ & 180698312 & 70306677 & 110391.635 & 749 \\
\hline 41 & 3_8376_10.OSCHP & $\mathrm{LOH}$ & 5 & $\mathrm{q} 21.1$ & 106861975 & 101206368 & 5655.607 & 9 \\
\hline 42 & 3_8376_10.OSCHP & $\mathrm{LOH}$ & 5 & $\mathrm{q} 21.3$ & 114957561 & 107853410 & 7104.151 & 33 \\
\hline 43 & 3_8376_10.OSCHP & $\mathrm{LOH}$ & 5 & $\mathrm{q} 22.3$ & 121539398 & 115180415 & 6358.983 & 20 \\
\hline 44 & 2_203344_15.OSCHP & $\mathrm{LOH}$ & 5 & $\mathrm{q} 23.2$ & 124880865 & 121481182 & 3399.683 & 11 \\
\hline 45 & 3_8376_10.OSCHP & $\mathrm{LOH}$ & 5 & $\mathrm{q} 23.3$ & 132783187 & 129632862 & 3150.325 & 34 \\
\hline 46 & 2_203344_15.OSCHP & $\mathrm{LOH}$ & 5 & q31.1 & 136935228 & 133568504 & 3366.724 & 33 \\
\hline 47 & 3_8376_10.OSCHP & $\mathrm{LOH}$ & 5 & $\mathrm{q} 31.2$ & 142559092 & 138965375 & 3593.717 & 106 \\
\hline 48 & 2_203344_15.OSCHP & $\mathrm{LOH}$ & 5 & q32 & 150654481 & 147480079 & 3174.402 & 48 \\
\hline 49 & 2_203344_15.OSCHP & $\mathrm{LOH}$ & 5 & q33.1 & 154336832 & 150789050 & 3547.782 & 21 \\
\hline 50 & 3_8376_10.OSCHP & $\mathrm{LOH}$ & 5 & q33.1 & 176675423 & 151738611 & 24936.812 & 137 \\
\hline 51 & 2_203344_15.OSCHP & $\mathrm{LOH}$ & 5 & $\mathrm{q} 33.2$ & 180698312 & 155277214 & 25421.098 & 200 \\
\hline
\end{tabular}


Table I. Continued.

\begin{tabular}{|c|c|c|c|c|c|c|c|c|}
\hline No. & Sample & Type & Chrom. & Cytoband & $\begin{array}{c}\text { Genomic } \\
\text { location start }\end{array}$ & $\begin{array}{c}\text { Genomic } \\
\text { location end }\end{array}$ & Size (Kbp) & Gene count \\
\hline 52 & 2_203344_15.OSCHP & $\mathrm{LOH}$ & 6 & $\mathrm{p} 25.3$ & 21704602 & 204908 & 21499.694 & 116 \\
\hline 53 & 1_189975.OSCHP & $\mathrm{LOH}$ & 6 & $\mathrm{p} 25.3$ & 58770502 & 204908 & 58565.594 & 708 \\
\hline 54 & 3_8376_10.OSCHP & $\mathrm{LOH}$ & 6 & q11.1 & 69746054 & 61886392 & 7859.662 & 8 \\
\hline 55 & 1_189975.OSCHP & $\mathrm{LOH}$ & 6 & q11.1 & 170913051 & 61886392 & 109026.659 & 512 \\
\hline 56 & 2_203344_15.OSCHP & $\mathrm{LOH}$ & 6 & $\mathrm{q} 22.32$ & 170913051 & 126471760 & 44441.291 & 261 \\
\hline 57 & 3_8376_10.OSCHP & $\mathrm{LOH}$ & 6 & $\mathrm{q} 23.3$ & 170913051 & 135739354 & 35173.697 & 205 \\
\hline 58 & 4_208156_15.OSCHP & $\mathrm{LOH}$ & 6 & $\mathrm{q} 23.3$ & 170913051 & 138266430 & 32646.621 & 189 \\
\hline 59 & 3_8376_10.OSCHP & $\mathrm{LOH}$ & 7 & p15.3 & 35873540 & 21882560 & 13990.98 & 118 \\
\hline 60 & 4_208156_15.OSCHP & $\mathrm{LOH}$ & 7 & $\mathrm{p} 22.3$ & 50700153 & 41420 & 50658.733 & 348 \\
\hline 61 & 1_189975.OSCHP & $\mathrm{LOH}$ & 8 & $\mathrm{p} 23.1$ & 26419805 & 8094762 & 18325.043 & 147 \\
\hline 62 & 4_208156_15.OSCHP & $\mathrm{LOH}$ & 8 & $\mathrm{p} 23.1$ & 27024823 & 8094762 & 18930.061 & 148 \\
\hline 63 & 3_8376_10.OSCHP & $\mathrm{LOH}$ & 8 & $\mathrm{p} 23.1$ & 30191040 & 8094762 & 22096.278 & 182 \\
\hline 64 & 1_189975.OSCHP & $\mathrm{LOH}$ & 8 & $\mathrm{p} 23.3$ & 7004147 & 172416 & 6831.731 & 36 \\
\hline 65 & 3_8376_10.OSCHP & $\mathrm{LOH}$ & 8 & $\mathrm{p} 23.3$ & 7004147 & 172416 & 6831.731 & 36 \\
\hline 66 & 4_208156_15.OSCHP & $\mathrm{LOH}$ & 8 & $\mathrm{p} 23.3$ & 7004147 & 172416 & 6831.731 & 36 \\
\hline 67 & 4_208156_15.OSCHP & $\mathrm{LOH}$ & 8 & $\mathrm{q} 11.21$ & 53114569 & 49845207 & 3269.362 & 5 \\
\hline 68 & 4_208156_15.OSCHP & $\mathrm{LOH}$ & 8 & q12.1 & 117682009 & 59515755 & 58166.254 & 254 \\
\hline 69 & 2_203344_15.OSCHP & $\mathrm{LOH}$ & 8 & q12.3 & 66046002 & 62996038 & 3049.964 & 12 \\
\hline 70 & 1_189975.OSCHP & $\mathrm{LOH}$ & 8 & q13.3 & 111154532 & 71428716 & 39725.816 & 192 \\
\hline 71 & 3_8376_10.OSCHP & $\mathrm{LOH}$ & 8 & $\mathrm{q} 24.22$ & 140789847 & 134986490 & 5803.357 & 10 \\
\hline 72 & 2_203344_15.OSCHP & $\mathrm{LOH}$ & 9 & $\mathrm{p} 22.3$ & 24559653 & 14364589 & 10195.064 & 59 \\
\hline 73 & 1_189975.OSCHP & $\mathrm{LOH}$ & 9 & $\mathrm{p} 24.3$ & 33434153 & 204737 & 33229.416 & 138 \\
\hline 74 & 4_208156_15.OSCHP & $\mathrm{LOH}$ & 9 & $\mathrm{q} 21.11$ & 78561334 & 70984371 & 7576.963 & 37 \\
\hline 75 & 1_189975.OSCHP & $\mathrm{LOH}$ & 9 & $\mathrm{q} 21.12$ & 141054761 & 73134143 & 67920.618 & 659 \\
\hline 76 & 3_8376_10.OSCHP & $\mathrm{LOH}$ & 9 & $\mathrm{q} 21.13$ & 99234997 & 74937502 & 24297.495 & 145 \\
\hline 77 & 2_203344_15.OSCHP & $\mathrm{LOH}$ & 9 & $\mathrm{q} 21.13$ & 93599890 & 79064623 & 14535.267 & 67 \\
\hline 78 & 3_8376_10.OSCHP & $\mathrm{LOH}$ & 9 & q31.1 & 136241639 & 107839840 & 28401.799 & 301 \\
\hline 79 & 4_208156_15.OSCHP & $\mathrm{LOH}$ & 9 & q33.2 & 141054761 & 125422864 & 15631.897 & 316 \\
\hline 80 & 1_189975.OSCHP & $\mathrm{LOH}$ & 10 & p15.3 & 32764613 & 126069 & 32638.544 & 188 \\
\hline 81 & 1_189975.OSCHP & $\mathrm{LOH}$ & 10 & $\mathrm{q} 23.1$ & 135434303 & 82575777 & 52858.526 & 437 \\
\hline 82 & 4_208156_15.OSCHP & $\mathrm{LOH}$ & 10 & $\mathrm{q} 23.1$ & 135434303 & 82843903 & 52590.4 & 437 \\
\hline 83 & 3_8376_10.OSCHP & $\mathrm{LOH}$ & 10 & $\mathrm{q} 23.1$ & 114381720 & 87268004 & 27113.716 & 267 \\
\hline 84 & 3_8376_10.OSCHP & $\mathrm{LOH}$ & 11 & $\mathrm{p} 11.2$ & 51575951 & 46089775 & 5486.176 & 59 \\
\hline 85 & 1_189975.OSCHP & $\mathrm{LOH}$ & 11 & $\mathrm{p} 11.2$ & 51575951 & 48040260 & 3535.691 & 18 \\
\hline 86 & 1_189975.OSCHP & $\mathrm{LOH}$ & 11 & p15.5 & 3789206 & 192763 & 3596.443 & 112 \\
\hline 87 & 4_208156_15.OSCHP & $\mathrm{LOH}$ & 11 & p15.5 & 27025877 & 192763 & 26833.114 & 361 \\
\hline 88 & 3_8376_10.OSCHP & $\mathrm{LOH}$ & 11 & $\mathrm{p} 15.5$ & 38786252 & 192763 & 38593.489 & 422 \\
\hline 89 & 4_208156_15.OSCHP & $\mathrm{LOH}$ & 11 & q12.2 & 63386750 & 60212296 & 3174.454 & 108 \\
\hline 90 & 1_189975.OSCHP & $\mathrm{LOH}$ & 11 & $\mathrm{q} 13.4$ & 80566396 & 70719896 & 9846.5 & 108 \\
\hline 91 & 4_208156_15.OSCHP & $\mathrm{LOH}$ & 11 & q14.1 & 134938847 & 82560444 & 52378.403 & 405 \\
\hline 92 & 3_8376_10.OSCHP & $\mathrm{LOH}$ & 11 & q14.1 & 93535839 & 84664703 & 8871.136 & 56 \\
\hline 93 & 3_8376_10.OSCHP & $\mathrm{LOH}$ & 11 & $\mathrm{q} 22.1$ & 118473385 & 99519603 & 18953.782 & 155 \\
\hline 94 & 1_189975.OSCHP & $\mathrm{LOH}$ & 11 & $\mathrm{q} 22.3$ & 116216759 & 108306235 & 7910.524 & 62 \\
\hline 95 & 1_189975.OSCHP & $\mathrm{LOH}$ & 12 & $\mathrm{p} 13.33$ & 12919325 & 189399 & 12729.926 & 215 \\
\hline 96 & 3_8376_10.OSCHP & $\mathrm{LOH}$ & 12 & $\mathrm{q} 13.13$ & 133818115 & 52051129 & 81766.986 & 724 \\
\hline 97 & 2_203344_15.OSCHP & $\mathrm{LOH}$ & 12 & q14.1 & 62234495 & 59059674 & 3174.821 & 3 \\
\hline 98 & 2_203344_15.OSCHP & $\mathrm{LOH}$ & 12 & $\mathrm{q} 21.33$ & 133818115 & 89779996 & 44038.119 & 388 \\
\hline 99 & 4_208156_15.OSCHP & $\mathrm{LOH}$ & 12 & $\mathrm{q} 23.1$ & 133818115 & 96564524 & 37253.591 & 340 \\
\hline 100 & 3_8376_10.OSCHP & $\mathrm{LOH}$ & 13 & q11 & 111956103 & 19084822 & 92871.281 & 429 \\
\hline 101 & 2_203344_15.OSCHP & $\mathrm{LOH}$ & 13 & q11 & 115103150 & 19084822 & 96018.328 & 460 \\
\hline 102 & 4_208156_15.OSCHP & $\mathrm{LOH}$ & 13 & q11 & 115103150 & 19084822 & 96018.328 & 460 \\
\hline
\end{tabular}


Table I. Continued.

\begin{tabular}{|c|c|c|c|c|c|c|c|c|}
\hline No. & Sample & Type & Chrom. & Cytoband & $\begin{array}{c}\text { Genomic } \\
\text { location start }\end{array}$ & $\begin{array}{c}\text { Genomic } \\
\text { location end }\end{array}$ & Size (Kbp) & Gene count \\
\hline 103 & 3_8376_10.OSCHP & $\mathrm{LOH}$ & 14 & $\mathrm{q} 11.2$ & 35930195 & 23299134 & 12631.061 & 116 \\
\hline 104 & 4_208156_15.OSCHP & LOH & 14 & $\mathrm{q} 23.1$ & 107282024 & 60071277 & 47210.747 & 465 \\
\hline 105 & 1_189975.OSCHP & $\mathrm{LOH}$ & 14 & $\mathrm{q} 23.1$ & 99873891 & 60436201 & 39437.69 & 283 \\
\hline 106 & 3_8376_10.OSCHP & LOH & 14 & $\mathrm{q} 32.2$ & 107282024 & 100785616 & 6496.408 & 170 \\
\hline 107 & 1_189975.OSCHP & $\mathrm{LOH}$ & 15 & $\mathrm{q} 11.2$ & 78938567 & 22752398 & 56186.169 & 617 \\
\hline 108 & 3_8376_10.OSCHP & $\mathrm{LOH}$ & 15 & $\mathrm{q} 11.2$ & 79548077 & 22752398 & 56795.679 & 624 \\
\hline 109 & 4_208156_15.OSCHP & $\mathrm{LOH}$ & 15 & $\mathrm{q} 11.2$ & 102397317 & 22752398 & 79644.919 & 807 \\
\hline 110 & 2_203344_15.OSCHP & LOH & 15 & $\mathrm{q} 24.2$ & 79167603 & 75948670 & 3218.933 & 42 \\
\hline 111 & 2_203344_15.OSCHP & $\mathrm{LOH}$ & 16 & $\mathrm{p} 11.2$ & 35271725 & 31842847 & 3428.878 & 16 \\
\hline 112 & 3_8376_10.OSCHP & $\mathrm{LOH}$ & 16 & p13.3 & 23792157 & 83886 & 23708.271 & 366 \\
\hline 113 & 1_189975.OSCHP & $\mathrm{LOH}$ & 16 & $\mathrm{p} 13.3$ & 35271725 & 83886 & 35187.839 & 535 \\
\hline 114 & 1_189975.OSCHP & $\mathrm{LOH}$ & 16 & $\mathrm{q} 11.2$ & 90158005 & 46461308 & 43696.697 & 420 \\
\hline 115 & 3_8376_10.OSCHP & $\mathrm{LOH}$ & 16 & $\mathrm{q} 11.2$ & 90158005 & 46461308 & 43696.697 & 420 \\
\hline 116 & 1_189975.OSCHP & $\mathrm{LOH}$ & 17 & p13.3 & 22217883 & 400958 & 21816.925 & 399 \\
\hline 117 & 2_203344_15.OSCHP & $\mathrm{LOH}$ & 17 & $\mathrm{p} 13.3$ & 22217883 & 400958 & 21816.925 & 399 \\
\hline 118 & 3_8376_10.OSCHP & $\mathrm{LOH}$ & 17 & $\mathrm{p} 13.3$ & 22217883 & 400958 & 21816.925 & 399 \\
\hline 119 & 4_208156_15.OSCHP & $\mathrm{LOH}$ & 17 & p13.3 & 22217883 & 400958 & 21816.925 & 399 \\
\hline 120 & 1_189975.OSCHP & $\mathrm{LOH}$ & 17 & $\mathrm{q} 11.1$ & 45863219 & 25326940 & 20536.279 & 472 \\
\hline 121 & 2_203344_15.OSCHP & $\mathrm{LOH}$ & 17 & q11.1 & 80263427 & 25326940 & 54936.487 & 952 \\
\hline 122 & 3_8376_10.OSCHP & LOH & 17 & q11.1 & 80263427 & 25326940 & 54936.487 & 952 \\
\hline 123 & 4_208156_15.OSCHP & $\mathrm{LOH}$ & 17 & $\mathrm{q} 11.1$ & 80263427 & 25326940 & 54936.487 & 952 \\
\hline 124 & 1_189975.OSCHP & $\mathrm{LOH}$ & 17 & $\mathrm{q} 23.2$ & 80263427 & 58390959 & 21872.468 & 320 \\
\hline 125 & 2_203344_15.OSCHP & $\mathrm{LOH}$ & 18 & $\mathrm{p} 11.32$ & 10493077 & 2063183 & 8429.894 & 44 \\
\hline 126 & 4_208156_15.OSCHP & $\mathrm{LOH}$ & 18 & $\mathrm{q} 12.1$ & 78007784 & 26057436 & 51950.348 & 215 \\
\hline 127 & 2_203344_15.OSCHP & $\mathrm{LOH}$ & 18 & $\mathrm{q} 12.2$ & 78007784 & 36335674 & 41672.11 & 172 \\
\hline 128 & 3_8376_10.OSCHP & $\mathrm{LOH}$ & 18 & $\mathrm{q} 12.3$ & 78007784 & 38349307 & 39658.477 & 169 \\
\hline 129 & 1_189975.OSCHP & $\mathrm{LOH}$ & 18 & $\mathrm{q} 12.3$ & 78007784 & 42908725 & 35099.059 & 162 \\
\hline 130 & 1_189975.OSCHP & $\mathrm{LOH}$ & 19 & $\mathrm{p} 13.3$ & 4448843 & 247231 & 4201.612 & 154 \\
\hline 131 & 4_208156_15.OSCHP & $\mathrm{LOH}$ & 19 & p13.3 & 6222353 & 247231 & 5975.122 & 196 \\
\hline 132 & 3_8376_10.OSCHP & LOH & 19 & p13.3 & 9033548 & 247231 & 8786.317 & 277 \\
\hline 133 & 2_203344_15.OSCHP & $\mathrm{LOH}$ & 19 & $\mathrm{q} 13.11$ & 59093239 & 35366074 & 23727.165 & 924 \\
\hline 134 & 4_208156_15.OSCHP & $\mathrm{LOH}$ & 19 & $\mathrm{q} 13.2$ & 56731955 & 42241444 & 14490.511 & 616 \\
\hline 135 & 1_189975.OSCHP & LOH & 19 & $\mathrm{q} 13.32$ & 59093239 & 46416646 & 12676.593 & 561 \\
\hline 136 & 4_208156_15.OSCHP & $\mathrm{LOH}$ & 20 & p13 & 16811434 & 69093 & 16742.341 & 139 \\
\hline 137 & 1_189975.OSCHP & $\mathrm{LOH}$ & 20 & $\mathrm{q} 11.22$ & 60126157 & 34313296 & 25812.861 & 250 \\
\hline 138 & 2_203344_15.OSCHP & $\mathrm{LOH}$ & 20 & $\mathrm{q} 13.2$ & 58259236 & 52721955 & 5537.281 & 49 \\
\hline 139 & 3_8376_10.OSCHP & $\mathrm{LOH}$ & 20 & $\mathrm{q} 13.2$ & 60139227 & 52771260 & 7367.967 & 57 \\
\hline 140 & 1_189975.OSCHP & $\mathrm{LOH}$ & 21 & $\mathrm{q} 11.2$ & 48097610 & 14344536 & 33753.074 & 295 \\
\hline 141 & 1_189975.OSCHP & $\mathrm{LOH}$ & 22 & q11.1 & 51213826 & 16054712 & 35159.114 & 549 \\
\hline 142 & 4_208156_15.OSCHP & $\mathrm{LOH}$ & 22 & q11.1 & 51213826 & 16054712 & 35159.114 & 549 \\
\hline 143 & 3_8376_10.OSCHP & $\mathrm{LOH}$ & 22 & $\mathrm{q} 11.21$ & 51213826 & 19939352 & 31274.474 & 492 \\
\hline 144 & 2_203344_15.OSCHP & $\mathrm{LOH}$ & 22 & $\mathrm{q} 11.21$ & 51213826 & 21028945 & 30184.881 & 467 \\
\hline 145 & 1_189975.OSCHP & $\mathrm{LOH}$ & $\mathrm{X}$ & p22.33 & 58412929 & 177941 & 58234.988 & 396 \\
\hline 146 & 3_8376_10.OSCHP & $\mathrm{LOH}$ & $X$ & $\mathrm{p} 22.33$ & 58412929 & 177941 & 58234.988 & 396 \\
\hline 147 & 2_203344_15.OSCHP & $\mathrm{LOH}$ & $\mathrm{X}$ & q11.1 & 65127774 & 61732393 & 3395.381 & 12 \\
\hline 148 & 3_8376_10.OSCHP & $\mathrm{LOH}$ & $\mathrm{X}$ & q11.1 & 76001785 & 61732393 & 14269.392 & 102 \\
\hline 149 & 1_189975.OSCHP & $\mathrm{LOH}$ & $\mathrm{X}$ & q11.1 & 155219364 & 61732393 & 93486.971 & 623 \\
\hline 150 & 4_208156_15.OSCHP & $\mathrm{LOH}$ & $\mathrm{X}$ & $\mathrm{q} 11.2$ & 67429457 & 63554561 & 3874.896 & 12 \\
\hline 151 & 3_8376_10.OSCHP & $\mathrm{LOH}$ & $\mathrm{X}$ & $\mathrm{q} 21.31$ & 92806132 & 88265772 & 4540.36 & 3 \\
\hline 152 & 3_8376_10.OSCHP & $\mathrm{LOH}$ & $\mathrm{X}$ & $\mathrm{q} 25$ & 129607422 & 125678360 & 3929.062 & 18 \\
\hline
\end{tabular}

LOH, loss of heterozygosity; Chrom., chromosome; 
Table II. The chromosomal regions showing chromosomal alterations identified in patients 1-2 showing sensitiveness for chemotherapy.

\begin{tabular}{|c|c|c|c|c|c|c|c|}
\hline No. & Type & Segment & Chrom. & $\begin{array}{c}\text { Genomic } \\
\text { location start }\end{array}$ & $\begin{array}{c}\text { Genomic } \\
\text { location end }\end{array}$ & Size (Kbp) & Cancer genes \\
\hline 1 & loh & LOH_2_15.OSCHP & 4 & 52684890 & 97836479 & 45151.589 & $\begin{array}{l}\text { FIP1L1, CHIC2, } \\
\text { PDGFRA, KIT, KDR }\end{array}$ \\
\hline 2 & loh & LOH_2_15.OSCHP & 6 & 204908 & 21704602 & 21499.694 & IRF4, DEK, \\
\hline 3 & loh & LOH_2_15.OSCHP & 9 & 14364589 & 24559653 & 10195.064 & $\begin{array}{l}\text { NFIB, MLLT3, } \\
\text { CDKN2A }\end{array}$ \\
\hline 4 & loh & LOH_2_15.OSCHP & 16 & 31842847 & 35271725 & 3428.878 & - \\
\hline 5 & loss & Loss1.5_2_15.OSCHP & 8 & 89900441 & 95759698 & 5859.257 & - \\
\hline
\end{tabular}

LOH, loss of heterozygosity; Chrom., chromosome.

Table III. The chromosomal regions with alterations identified in patients 3 and 4, who showed chemoresistance.

\begin{tabular}{|c|c|c|c|c|c|c|c|}
\hline No. & Type & Segment & Chrom. & $\begin{array}{l}\text { Genomic } \\
\text { location start }\end{array}$ & $\begin{array}{l}\text { Genomic } \\
\text { location end }\end{array}$ & Size & Genes \\
\hline 1 & loh & LOH_3_10.OSCHP & 3 & 63410 & 11539955 & 11476.545 & SRGAP3, FANCD2, VHL \\
\hline 2 & loh & LOH_3_10.OSCHP & 3 & 46001062 & 51927415 & 5926.353 & SETD2 \\
\hline 3 & loh & LOH_3_10.OSCHP & 3 & 157426328 & 168219437 & 10793.109 & MLF1 \\
\hline 4 & loss & Loss1.0_4_15.OSCHP & 4 & 104892789 & 126864721 & 21971.932 & TET2, IL2 \\
\hline 5 & loss & Loss1.0_4_15.OSCHP & 4 & 160026316 & 190915650 & 30889.334 & \\
\hline 6 & loss & Loss1.0_4_15.OSCHP & 5 & 51505664 & 113875957 & 62370.293 & IL6ST, PIK3R1, APC \\
\hline 7 & loh & LOH_3_10.OSCHP & 7 & 21882560 & 35873540 & 13990.98 & $\begin{array}{l}\text { HNRN, PA2B1, HOXA9, } \\
\text { HOXA11, HOXA13, JAZF1 }\end{array}$ \\
\hline 8 & loss & Loss1.3_3_10.OSCHP & 7 & 23008207 & 27115718 & 4107.511 & \\
\hline 9 & loss & Loss1.7_3_10.OSCHP & 7 & 27127230 & 32219657 & 5092.427 & \\
\hline 10 & loss & Loss1.3_3_10.OSCHP & 7 & 32240424 & 32817742 & 577.318 & \\
\hline 11 & loss & Loss1.0_4_15.OSCHP & 8 & 172416 & 26170975 & 25998.559 & PCM1 \\
\hline 12 & loss & Loss1.5_4_15.OSCHP & 9 & 126044009 & 136147702 & 10103.693 & $\begin{array}{l}\text { SET, FNBP1, ABL1, } \\
\text { NUP214, TSC1, RALGDS }\end{array}$ \\
\hline 13 & loss & LOH_3_8376_10.OSCHP & 10 & 87268004 & 114381720 & 27113.716 & $\begin{array}{l}\text { BMPR1A, PTEN, TLX1, } \\
\text { NFKB2, SUFU, NT5C2, } \\
\text { VTI1A, TCF7L2, FGFR2 }\end{array}$ \\
\hline 14 & loh & LOH_4_15.OSCHP & 11 & 192763 & 27025877 & 26833.114 & $\begin{array}{l}\text { HRAS, CARS, NUP98, } \\
\text { LMO1, FANCF }\end{array}$ \\
\hline 15 & loh & LOH_3_10.OSCHP & 11 & 84664703 & 93535839 & 8871.136 & PICALM \\
\hline 16 & loss & LOH_3_8376_10.OSCHP & 14 & 100785616 & 107282024 & 6496.408 & \\
\hline 17 & loss & Loss1.3_3_10.OSCHP & 15 & 71156952 & 79214215 & 8057.263 & PML \\
\hline 18 & loss & Loss1.5_4_15.OSCHP & 16 & 18069547 & 19266457 & 1196.91 & \\
\hline 19 & loss & Loss1.0_4_15.OSCHP & 19 & 247231 & 5655792 & 5408.561 & $\begin{array}{l}\text { FSTL3, STK11, TCF3, } \\
\text { GNA11, MAP2K2, SH3GL1, } \\
\text { MLLT1 }\end{array}$ \\
\hline 20 & loss & Loss1.7_3_10.OSCHP & 19 & 1550649 & 8086055 & 6535.406 & \\
\hline
\end{tabular}

LOH, loss of heterozygosity; Chrom., chromosome.

$<50 \%$ (15). Therefore, novel agents are necessary to improve the outcomes for ovarian cancer patients. In addition, it is important to understand and define the patients that are likely to be sensitive to treatment and have resistant disease. Ovarian cancer is a lethal gynecological disease that is characterized by peritoneal metastasis and increased resistance to conventional chemotherapies (16). This increased resistance and the ability of the cancer to spread is often attributed to the formation of 


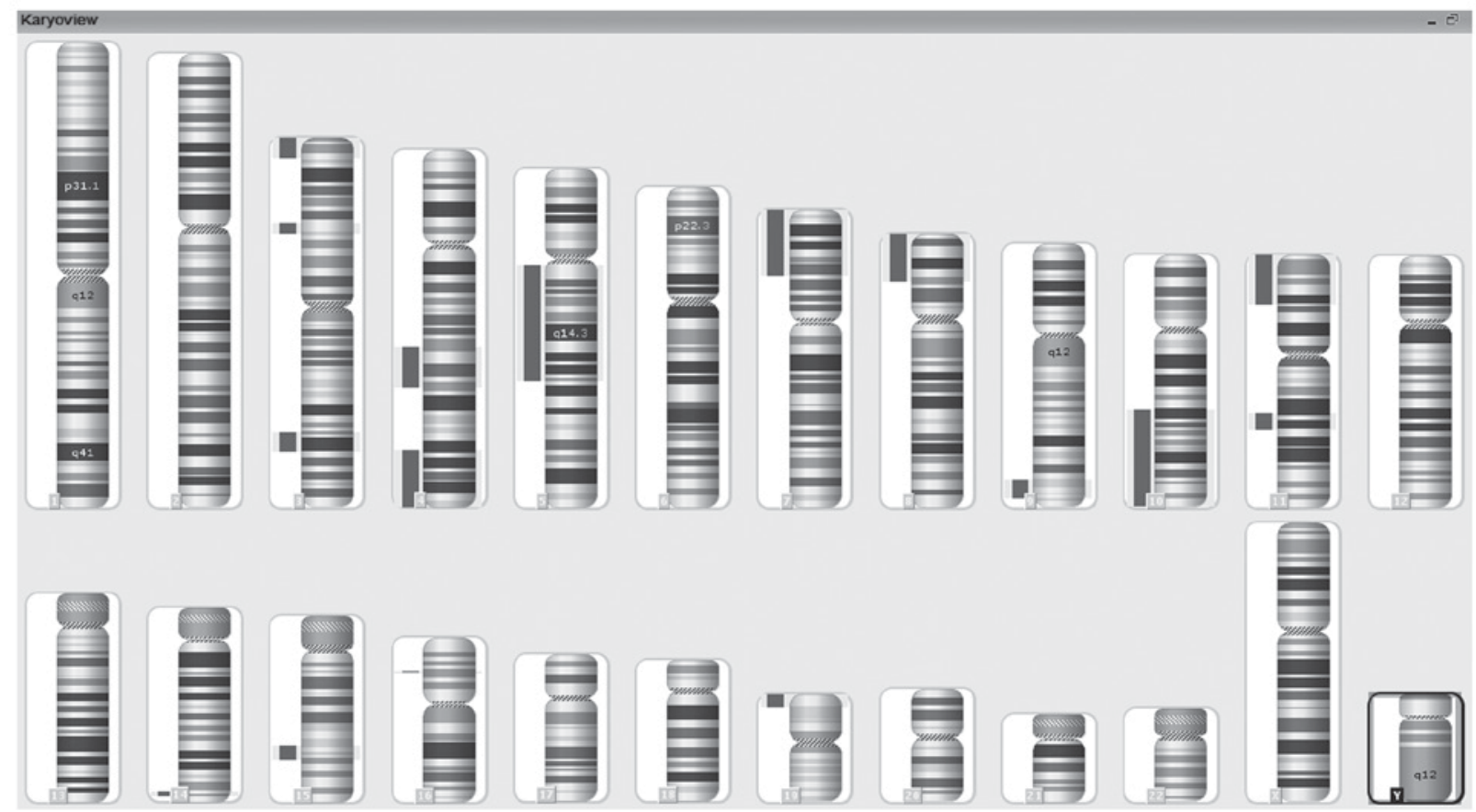

Figure 2. A karyogram showing the chromosomal alterations identified in patients 1 and 2, who showed chemosensitivity.

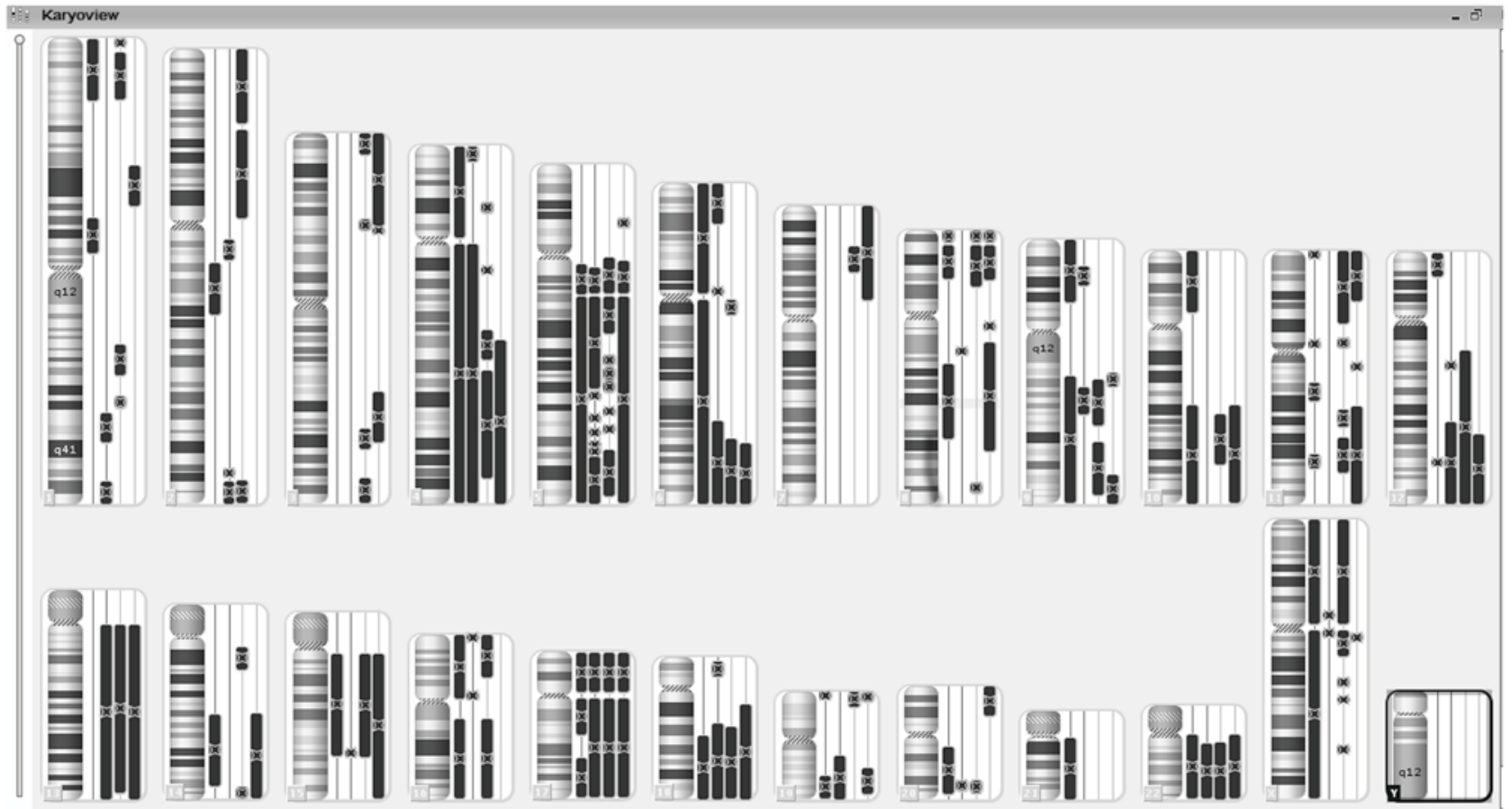

Figure 3. A karyogram showing the chromosomal regions with chromosomal alterations identified in patients 3 and 4 , who showed chemoresistance.

multicellular aggregates or spheroids in the peritoneal cavity, which seed to abdominal surfaces and organs (17). Since the presence of metastatic implants is a predictor of poor survival, a better understanding of how spheroids form is critical to improving patient outcome, and may result in the identification of novel therapeutic targets (16). The most widely used tumor marker in ovarian cancer, often considered the 'gold standard', is CA125, which is elevated in $80 \%$ of epithelial ovarian cancers (EOCs) (18). CA125 is elevated in $50-60 \%$ of patients with stage I EOC and $75-90 \%$ of patients with advanced stage EOC (19). The sensitivity of CA125 to identify early stage disease is limited as a screening tool (20). Reliable clinical evidence demonstrates that human epididymis protein (HE4), used alone or in combination with CA125, substantially improves the accuracy of screening and/or disease monitoring (21). HE4, found primarily in the epithelia of normal genital tissues is elevated in EOC (22). HE4 has greater specificity in the premenopausal age group than CA125, since it does not appear to be expressed 
Table IV. List of the drivers somatic mutations implemented into Affymetrix OncoScan Arrays.

\begin{tabular}{|c|c|c|c|c|}
\hline Mutation & Type & AA change & CDS change & Cosmic ID \\
\hline NRAS:p.Q61R:c.182A>G & Missense & p.Q61R & c. $182 \mathrm{~A}>\mathrm{G}$ & COSM584 \\
\hline NRAS:p.Q61L:c.182A>T & Missense & p.Q61L & c. $182 \mathrm{~A}>\mathrm{T}$ & COSM583 \\
\hline NRAS:p.Q61K:c.181C>A & Missense & p.Q61K & c. $181 \mathrm{C}>\mathrm{A}$ & COSM580 \\
\hline NRAS:p.G12V:c.35G>T & Missense & p.G12V & c. $35 \mathrm{G}>\mathrm{T}$ & COSM566 \\
\hline NRAS:p.G12D:c.35G>A & Missense & p.G12D & c. $35 \mathrm{G}>\mathrm{A}$ & COSM564 \\
\hline NRAS:p.G12S/C:c.34G>A/T & Missense & p.G12SIlp.G12C & c. $34 \mathrm{G}>\mathrm{A} \| \mathrm{lc} .34 \mathrm{G}>\mathrm{T}$ & COSM563IICOSM562 \\
\hline IDH1:p.R132H:c.395G>A & Missense & p.R132H & c. $395 \mathrm{G}>\mathrm{A}$ & COSM28746 \\
\hline PIK3CA:p.E542K:c.1624G>A & Missense & p.E542K & c. $1624 \mathrm{G}>\mathrm{A}$ & COSM760 \\
\hline PIK3CA:p.E545K:c.1633G>A & Missense & p.E545K & c. $1633 \mathrm{G}>\mathrm{A}$ & COSM763 \\
\hline PIK3CA:p.Q546K:c.1636C>A & Missense & p.Q546K & c. $1636 \mathrm{C}>\mathrm{A}$ & COSM766 \\
\hline PIK3CA:p.H1047R:c.3140A>G & Missense & p.H1047R & c. $3140 A>G$ & COSM775 \\
\hline PIK3CA:p.H1047L:c.3140A>T & Missense & p.H1047L & c. $3140 \mathrm{~A}>\mathrm{T}$ & COSM776 \\
\hline EGFR:p.G719S:c.2155G>A & Missense & p.G719S & c. $2155 \mathrm{G}>\mathrm{A}$ & COSM6252 \\
\hline EGFR:p.G719C:c.2155G>T & Missense & p.G719C & c. $2155 \mathrm{G}>\mathrm{T}$ & COSM6253 \\
\hline EGFR:p.G719A:c.2156G>C & Missense & p.G719A & c. $2156 \mathrm{G}>\mathrm{C}$ & COSM6239 \\
\hline $\begin{array}{l}\text { EGFR:p.E746_A750del:c. } \\
\text { 2235_2249del15 }\end{array}$ & In-frame & p.E746_A750delELREA & c.2235_2249del15 & COSM6223 \\
\hline $\begin{array}{l}\text { EGFR:p.E746_A750del:c. } \\
\text { 2236_2250del15 }\end{array}$ & In-frame & p.E746_A750delELREA & c.2236_2250del15 & COSM6225 \\
\hline $\begin{array}{l}\text { EGFR:p.E746_T751>A:c. } \\
\text { 2237_2251del15 }\end{array}$ & $\begin{array}{l}\text { Deletion } \\
\text { In-frame }\end{array}$ & p.E746_T751>A & c.2237_2251del15 & COSM12678 \\
\hline $\begin{array}{l}\text { EGFR:p.L747_E749P/del:c. } \\
\text { 2239_2248>C/G }\end{array}$ & Various & $\begin{array}{l}\text { p.L747_A750>Pllp.L747_ } \\
\text { E749delLRE }\end{array}$ & $\begin{array}{l}\text { c.2239_2248TTA } \\
\text { AGAGAAG >Cllc. } \\
\text { 2239_2247 } \\
\text { delTTAAGAGAA }\end{array}$ & $\begin{array}{l}\text { COSM12 } \\
\text { 382IICOSM6218 }\end{array}$ \\
\hline $\begin{array}{l}\text { EGFR:p.L747_T751del:c. } \\
\text { 2240_2254del15 }\end{array}$ & In-Frame & p.L747_T751delLREAT & c.2240_2254del15 & COSM12369 \\
\hline $\begin{array}{l}\text { EGFR:p.L747_P753>S:c. } \\
\text { 2240_2257del18 }\end{array}$ & $\begin{array}{l}\text { Deletion } \\
\text { In-frame }\end{array}$ & p.L747_P753>S & c.2240_2257del18 & COSM12370 \\
\hline $\begin{array}{l}\text { EGFR:p.V769_D770insASV:c. } \\
\text { 2307_2308ins9 }\end{array}$ & In-frame & p.V769_D770insASV & $\begin{array}{l}\text { c.2307_2308ins } \\
\text { GCCAGCGTG }\end{array}$ & COSM12376 \\
\hline $\begin{array}{l}\text { EGFR:p.D770_N771insSVD:c. } \\
\text { 2311_2312ins9 }\end{array}$ & In-frame & p.D770_N771insSVD & $\begin{array}{l}\text { c.2311_2312ins } \\
\text { GCGTGGACA }\end{array}$ & COSM13428 \\
\hline $\begin{array}{l}\text { EGFR:p.H773_V774insNPH:c. } \\
\text { 2319_2320ins9 }\end{array}$ & In-frame & p.H773_V774insNPH & $\begin{array}{l}\text { c.2319_2320ins } \\
\text { AACCCCCAC }\end{array}$ & COSM12381 \\
\hline EGFR:p.T790M:c.2369C>T & Missense & p.T790M & c. $2369 \mathrm{C}>\mathrm{T}$ & COSM6240 \\
\hline EGFR:p.L858R:c.2573T>G & Missense & p.L858R & c. $2573 \mathrm{~T}>\mathrm{G}$ & COSM6224 \\
\hline EGFR:p.L861Q:c.2582T>A & Missense & p.L861Q & c. $2582 \mathrm{~T}>\mathrm{A}$ & COSM6213 \\
\hline BRAF:p.V600K:c.1798_1799GT>AA & Missense & p.V600K & c.1798_1799GT>AA & COSM473 \\
\hline BRAF:p.V600E:c.1799T>A & Missense & p.V600E & c. $1799 \mathrm{~T}>\mathrm{A}$ & COSM476 \\
\hline BRAF:p.G469E:c.1406G>A & Missense & p.G469E & c. $1406 \mathrm{G}>\mathrm{A}$ & COSM461 \\
\hline BRAF:p.G469A:c.1406G>C & Missense & p.G469A & c. $1406 \mathrm{G}>\mathrm{C}$ & COSM460 \\
\hline PTEN:p.R130G:c.388C>G & Missense & p.R130G & c. $388 \mathrm{C}>\mathrm{G}$ & COSM5219 \\
\hline PTEN:p.R130*:c.388C>T & Nonsense & p.R130* & c. $388 \mathrm{C}>\mathrm{T}$ & COSM5152 \\
\hline PTEN:p.R130Q/fs*4:c.389G>A/delG & Various & p.R130Q\|lp.R130fs*4 & $\begin{array}{l}\text { c.389G }>\text { Allc. } \\
\text { 389delG }\end{array}$ & $\begin{array}{l}\text { COSM5033॥ } \\
\text { COSM5817 }\end{array}$ \\
\hline PTEN:p.R159S:c.477G>T & Missense & p.R159S & c. $477 \mathrm{G}>\mathrm{T}$ & COSM5287 \\
\hline PTEN:p.R233*:c.697C>T & Nonsense & p.R233* & c. $697 \mathrm{C}>\mathrm{T}$ & COSM5154 \\
\hline PTEN:p.P248fs*5:c.741_742insA & Frame-Shift & p.P248fs*5 & c.741_742insA & COSM4986 \\
\hline PTEN:p.K267fs" 9:c.800delA & Frame-Shift & p.K267fs"9 & c.800delA & COSM5809 \\
\hline KRAS:p.A146P:c.436G>C & Missense & p.A146P & c. $436 \mathrm{G}>\mathrm{C}$ & COSM19905 \\
\hline KRAS:p.Q61H:c.183A>T & Missense & p.Q61H & c. $183 \mathrm{~A}>\mathrm{T}$ & COSM555 \\
\hline KRAS:p.Q61H:c.183A>C & Missense & p.Q61H & c. $183 \mathrm{~A}>\mathrm{C}$ & COSM554 \\
\hline
\end{tabular}


Table IV. Continued.

\begin{tabular}{|c|c|c|c|c|}
\hline Mutation & Type & AA change & CDS change & Cosmic ID \\
\hline KRAS:p.Q61K/K:c.180_181TC>TA/AA & Missense & p.Q61K & $\begin{array}{l}\text { c. } 181 \mathrm{C}>\text { Allc. } \\
180 \_181 \mathrm{TC}>\mathrm{AA}\end{array}$ & $\begin{array}{l}\text { COSM549\| } \\
\text { COSM87298 }\end{array}$ \\
\hline KRAS:p.G13D:c.38G>A & Missense & p.G13D & c. $38 \mathrm{G}>\mathrm{A}$ & COSM532 \\
\hline KRAS:p.G12D/V:c.35G>A/T & Missense & p.G12D\|lp.G12V & c. $35 \mathrm{G}>$ Allc. $35 \mathrm{G}>\mathrm{T}$ & COSM521IICOSM520 \\
\hline KRAS:p.G12A:c.35G>C & Missense & p.G12A & c. $35 \mathrm{G}>\mathrm{C}$ & COSM522 \\
\hline KRAS:p.G12C/S:c.34G>T/A & Missense & p.G12Cllp.G12S & c. $34 \mathrm{G}>\mathrm{T} \| \mathrm{c} .34 \mathrm{G}>\mathrm{A}$ & COSM516"ICOSM517 \\
\hline IDH2:p.R172K:c.515G>A & Missense & p.R172K & c. $.515 \mathrm{G}>\mathrm{A}$ & COSM33733 \\
\hline IDH2:p.R140Q:c.419G>A & Missense & p.R140Q & c. $419 \mathrm{G}>\mathrm{A}$ & COSM41590 \\
\hline TP53:p.R306*:c.916C>T & Nonsense & p.R306* & c. $916 \mathrm{C}>\mathrm{T}$ & COSM10663 \\
\hline TP53:p.R282W:c.844C>T & Missense & p.R282W & c. $844 \mathrm{C}>\mathrm{T}$ & COSM10704 \\
\hline TP53:p.R273H/L:c.818G>A/T & Missense & p.R273HIlp.R273L & $\begin{array}{l}\text { c. } 818 \mathrm{G}>\text { Allc. } \\
818 \mathrm{G}>\mathrm{T}\end{array}$ & $\begin{array}{l}\text { COSM10660॥ } \\
\text { COSM10779 }\end{array}$ \\
\hline TP53:p.R273C/S:c.817C>T/A & Missense & p.R273Cllp.R273S & $\begin{array}{l}\text { c. } 817 \mathrm{C}>\mathrm{T} \| \mathrm{lc} . \\
817 \mathrm{C}>\mathrm{A}\end{array}$ & $\begin{array}{l}\text { COSM10659\| } \\
\text { COSM43909 }\end{array}$ \\
\hline TP53:p.R249S:c.747G>T & Missense & p.R249S & c. $747 \mathrm{G}>\mathrm{T}$ & COSM10817 \\
\hline TP53:p.R248Q/L:c.743G>A/T & Missense & p.R248Q\|lp.R248L & $\begin{array}{l}\text { c. } 743 \mathrm{G}>\text { Allc. } \\
743 \mathrm{G}>\mathrm{T}\end{array}$ & $\begin{array}{l}\text { COSM10662॥ } \\
\text { COSM6549 }\end{array}$ \\
\hline TP53:p.R248W:c.742C>T & Missense & p.R248W & c. $742 \mathrm{C}>\mathrm{T}$ & COSM10656 \\
\hline TP53:p.G245S/C:c.733G>A/T & Missense & p.G245SIlp.G245C & $\begin{array}{l}\text { c.733G }>\text { Allc. } \\
733 \mathrm{G}>\mathrm{T}\end{array}$ & $\begin{array}{l}\text { COSM6932॥ } \\
\text { COSM11081 }\end{array}$ \\
\hline TP53:p.Y220C:c.659A>G & Missense & p.Y220C & c. $659 \mathrm{~A}>\mathrm{G}$ & COSM10758 \\
\hline TP53:p.R213*:c.637C>T & Nonsense & p.R213* & c. $637 \mathrm{C}>\mathrm{T}$ & COSM10654 \\
\hline TP53:p.R196*:c.586C>T & Nonsense & p.R196* & c. $.586 \mathrm{C}>\mathrm{T}$ & COSM10705 \\
\hline TP53:p.H179R:c.536A>G & Missense & p.H179R & c. $536 \mathrm{~A}>\mathrm{G}$ & COSM10889 \\
\hline TP53:p.C176F:c.527G>T & Missense & p.C176F & c. $527 \mathrm{G}>\mathrm{T}$ & COSM10645 \\
\hline TP53:p.R175H:c.524G>A & Missense & p.R175H & c. $524 \mathrm{G}>\mathrm{A}$ & COSM10648 \\
\hline TP53:p.Y163C:c.488A>G & Missense & p.Y163C & c. $488 \mathrm{~A}>\mathrm{G}$ & COSM10808 \\
\hline TP53:p.V157F:c.469G>T & Missense & p.V157F & c. $469 \mathrm{G}>\mathrm{T}$ & COSM10670 \\
\hline
\end{tabular}

at high levels in benign conditions (23-25). The strongest risk factor of developing ovarian cancer is a family history of breast and ovarian cancer. It is known that $\sim 15 \%$ of ovarian cancer patients in the Polish population carry mutations in the BRCAl and $B R C A 2$ genes (26). A small number of cases are also associated with Lynch syndrome and mutations in $h M L H 1, h M S H 2$, hMSH6, PMS1 and PMS2 in mismatch repair genes (27). Chemotherapy resistance is a common problem faced by patients diagnosed with EOC $(28,29)$. Currently there are no specific or sensitive clinical biomarkers that may be implemented to identify chemotherapy resistance and provide insight into prognosis. Resistance of tumors to chemotherapeutic drugs remains a major clinical challenge for ovarian cancer treatment. The limitations of clinical chemotherapy have been ascribed primarily to mechanisms that mediate drug resistance at the cellular level (30). Previous studies suggest that tumor cells have the ability to regulate genes that help to export, decrease uptake, or increase the metabolism of chemotherapeutic drugs. Newer data also suggest that interactions between tumor cells and the surrounding microenvironment allow for increased resistance of tumor cells to chemotherapy (31). It has been observed that although $40-60 \%$ of patients achieve a complete clinical response to first-line chemotherapy treatment $\sim 50 \%$ of these patients relapse within 5 years and only $10-15 \%$ of patients presenting with advanced stage disease achieve long-term remission (32). It is hypothesized that the high relapse rate is, at least in part, due to resistance to chemotherapy, which may be inherent or acquired by altered gene expression. The patient response to chemotherapy for ovarian cancer is extremely heterogeneous and there are currently no tools to aid the prediction of sensitivity or resistance to chemotherapy and allow treatment stratification (8). Such a tool may markedly improve patient survival by identifying the most appropriate treatment on a patient-specific basis. A clinically applicable gene signature capable of predicting patient response to chemotherapy has not yet been identified. Research into a predictive model, as opposed to a prognostic model, may be highly beneficial and aid the identification of the most suitable treatment for patients. Although it has not yet been accomplished, progress within the field suggests that the development of a predictive model is possible (8). There is considerable variability between the approaches and success of existing studies in the literature, and there have been high levels of variation in the explanatory genes identified (13). The present study hypothesizes that, if more attention is paid to selecting the patients included, to control for treatment history, these gene signatures may be simplified and 
models that are able to predict the response to treatment may be developed.

Targeting molecular signatures, as well as signal transduction pathways for tumor sensitivity and resistance is essential for treatment and improving overall survival in patients with ovarian cancer (33). At present, an efficient molecular diagnostics for patients has not been established. The major goal of the present study was to reveal molecular hallmarks associated with, or even responsible for, the response of a patient to standard treatment. This knowledge facilitates the design and implementation of new therapies based on the genetic defect type. The identification of molecular signatures associated with chemo-response is a recent area of investigation. In ovarian adenocarcinoma, the OncoScan microarray technology has been performed to find genetic markers and locations that would be relevant in the prediction of response to chemotherapy. The OncoScan assay is efficient for the analysis of FFPE samples (14).

For the purposes of the present study, patients were divided into two categories, according to responsiveness to chemotherapy. In microarray analysis, the distribution of specific genetic factors between patients was compared. Significant variances in the occurrence of rearrangements were detected for both amplifications (gains) and deletions (losses). Deletions were more frequent in patients showing chemoresistance (14 losses) than in patients presenting with chemosensitivity (1 loss). However, none of the deletions were present in both patients in the same group. This discrepancy between the two patients in each cohort shows a high genetic heterogeneity of tumors. Detailed mapping data also revealed information on the $\mathrm{LOH}$. The $\mathrm{LOH}$ phenomenon is of particular importance since it enables the tracing of loss of the normal alleles of tumor suppressor genes, to determine the tumor phenotype. Therefore, locations presenting high frequency of LOH are attractive candidates for harboring tumor suppressor mutations. In the present study, similar amounts of LOH were present in the two cohorts. In addition, the majority of the samples showed LOH at several loci. Numerous loci with LOH were common between the two cohorts. However, certain LOH were typical for patients with resistance to chemotherapy or patients presenting with chemosensitivity. Regions of typical LOH for chemosensitivity were located on chromosomes 4 (p16.3, q11) and 6 (p25.3) in the present study, whereas LOH associated with loci 3p21.3, 3p26.3, 6q23.3 and 11q14.1 were found exclusively in the chemoresistant cases.

The assessment of $\mathrm{LOH}$ in EOC focused on the role of genes located on the short arm of chromosome 3 (3p) in the development of disease. Deletions in regions 3p21.3 and 3 p26.3 are common for such cases (34).

$\mathrm{LOH}$ in 6q23.3 affects the genes MYB, TNFAIP3 and ECT2 L. Only TNFAIP3 has been implicated in the inhibition of programmed cell death is and suggested to be a tumor suppressor gene (35). At present, the function the remaining genes is not associated with the pathogenesis of ovarian cancer. Furthermore, Shridhar et al (36) reported that deletion of the $6 \mathrm{q} 23.3$ region, which commonly presents $\mathrm{LOH}$ in ovarian cancer.

Notably, the commonly mutated genes for EOC, namely: CDH1; PRKN; BRCA1/2; and AKT1 were not identified in the present study. However, in patient 4 , who showed chemotherapy resistance, a somatic PIK3CA mutation was identified. Mutation in this gene has been previously associated with ovarian cancer (37). Certain studies have confirmed that the PIK3CA/Akt/mammalian target of rapamycin pathway is commonly dysregulated in ovarian cancers $(38,39)$.

Chemotherapy response in ovarian cancer is a complex and unpredictable process that determines the course of the disease. In the present study, genetic regions associated with ovarian cancer that may play an important role in the context of treatment response were identified. However, additional studies on a larger cohort of patients are required, in order to reveal crucial pathways and molecular determinants that directly influence the disease course and its aggressiveness.

\section{Acknowledgements}

This study was supported by the Polish Ministry of Science and Education (grant no. 789/FNiTP/162/2013).

\section{References}

1. Jemal A, Bray F, Center MM, Ferlay J, Ward E and Forman D: Global cancer statistics. CA Cancer J Clin 61: 69-90, 2011.

2. Siegel R, Ma J, Zou Z and Jemal A: Cancer statistics, 2014. CA Cancer J Clin 64: 9-29, 2014.

3. Potrykowska A, Strzelecki Z, Szymborski J and Witkowski J (eds): Cancer incidence and mortality versus the demographic situation of Poland. In: Rządowa Rada Ludnościowa, Warsaw, pp117-130, 2014 (In Polish).

4. Paik ES, Lee YY, Lee EJ, Choi CH, Kim TJ, Lee JW, Bae DS and Kim BG: Survival analysis of revised 2013 FIGO staging classification of epithelial ovarian cancer and comparison with previous FIGO staging classification. Obstet Gynecol Sci 58: 124-134, 2015.

5. Suh DH, Kim TH, Kim JW, Kim SY, Kim HS, Lee TS, Chung HH, Kim YB, Park NH and Song YS: Improvements to the FIGO staging for ovarian cancer: Reconsideration of lymphatic spread and intraoperative tumor rupture. J Gynecol Oncol 24: 352-358, 2013.

6. van der Burg ME, van Lent M, Buyse M, Kobierska A, Colombo N, Favalli G, Lacave AJ, Nardi M, Renard J and Pecorelli S: The effect of debulking surgery after induction chemotherapy on the prognosis in advanced epithelial ovarian cancer. Gynecological cancer cooperative group of the European Organization for research and treatment of cancer. N Engl J Med 332: 629-634, 1995.

7. Raja FA, Chopra N and Ledermann JA: Optimal first-line treatment in ovarian cancer. Ann Oncol 23 (Suppl 10): x118-x127, 2012.

8. Lloyd KL, Cree IA and Savage RS: Prediction of resistance to chemotherapy in ovarian cancer: A systematic review. BMC Cancer 15: 117, 2015.

9. Pliarchopoulou K and Pectasides D: Epithelial ovarian cancer: Focus on targeted therapy. Crit Rev Oncol Hematol 79: 17-23, 2011.

10. Zhu LC, Gao J, Hu ZH, Schwab CL, Zhuang HY, Tan MZ, Yan LM, Liu JJ, Zhang DY and Lin B: Membranous expressions of Lewis y and CAM-DR-related markers are independent factors of chemotherapy resistance and poor prognosis in epithelial ovarian cancer. Am J Cancer Res 5: 830-843, 2015.

11. Vinogradov S and Wei X: Cancer stem cells and drug resistance: The potential of nanomedicine. Nanomedicine (Lond) 7: 597-615, 2012.

12. Markman M and Bookman MA: Second-line treatment of ovarian cancer. Oncologist 5: 26-35, 2000.

13. Cooley M, Fang P, Fang F, Nephew KP and Chien J: Molecular determinants of chemotherapy resistance in ovarian cancer. Pharmacogenomics 16: 1763-1767, 2015.

14. Foster JM, Oumie A, Togneri FS, Vasques FR, Hau D, Taylor M, Tinkler-Hundal E, Southward K, Medlow P, McGreeghanCrosby K, et al: Cross-laboratory validation of the OncoScan ${ }^{\circledR}$ FFPE Assay, a multiplex tool for whole genome tumour profiling. BMC Med Genomics 8: 5, 2015. 
15. Bast RC Jr, Hennessy B and Mills GB: The biology of ovarian cancer: New opportunities for translation. Nat Rev Cancer 9: 415-428, 2009

16. Musrap N, Tuccitto A, Karagiannis GS, Saraon P, Batruch I and Diamandis EP: Comparative proteomics of ovarian cancer aggregate formation reveals an increased expression of calcium-activated chloride channel regulator 1 (CLCA1). J Biol Chem 290: 17218-17227, 2015.

17. Burleson KM, Casey RC, Skubitz KM, Pambuccian SE, Oegema TR Jr and Skubitz AP: Ovarian carcinoma ascites spheroids adhere to extracellular matrix components and mesothelial cell monolayers. Gynecol Oncol 93: 170-181, 2004.

18. Høgdall E: Cancer antigen 125 and prognosis. Curr Opin Obstet Gynecol 20: 4-8, 2008.

19. Gadducci A, Cosio S, Fanucchi A, Negri S, Cristofani R and Genazzani AR: The predictive and prognostic value of serum CA 125 half-life during paclitaxel/platinum-based chemotherapy in patients with advanced ovarian carcinoma. Gynecol Oncol 93: 131-136, 2004

20. Menon U, Skates SJ, Lewis S, Rosenthal AN, Rufford B, Sibley K Macdonald N, Dawnay A, Jeyarajah A, Bast RC Jr, et al: Prospective study using the risk of ovarian cancer algorithm to screen for ovarian cancer. J Clin Oncol 23: 7919-7926, 2005.

21. Hasanbegovic L, Alicelebic S and Sljivo N: Comparison of specific ovarian tumor markers by elecsys analyzer 2010. Acta Inform Med 23: 86-89, 2015.

22. Hellström I, Raycraft J, Hayden-Ledbetter M, Ledbetter JA Schummer M, McIntosh M, Drescher C, Urban N and Hellström KE: The HE4 (WFDC2) protein is a biomarker for ovarian carcinoma. Cancer Res 63: 3695-3700, 2003

23. Moore RG, MacLaughlan S and Bast RC Jr: Current state of biomarker development for clinical application in epithelial ovarian cancer. Gynecol Oncol 116: 240-245, 2010.

24. Huhtinen K, Suvitie P, Hiissa J, Junnila J, Huvila J, Kujari H, Setälä M, Härkki P, Jalkanen J, Fraser J, et al: Serum HE4 concentration differentiates malignant ovarian tumours from ovarian endometriotic cysts. Br J Cancer 100: 1315-1319, 2009.

25. Moore RG, Miller MC, Steinhoff MM, Skates SJ, Lu KH, Lambert-Messerlian G and Bast RC Jr: Serum HE4 levels are less frequently elevated than CA125 in women with benign gynecologic disorders. Am J Obstet Gynecol 206: 351.e1-8, 2012.

26. Górski B, Byrski T, Huzarski T, Jakubowska A, Menkiszak J, Gronwald J, Pluzańska A, Bebenek M, Fischer-Maliszewska L, Grzybowska E, et al: Founder mutations in the BRCA1 gene in Polish families with breast-ovarian cancer. Am J Hum Genet 66 1963-1968, 2000.

27. Herman JG, Umar A, Polyak K, Graff JR, Ahuja N, Issa JP, Markowitz S, Willson JK, Hamilton SR, Kinzler KW, et al: Incidence and functional consequences of hMLH1 promoter hypermethylation in colorectal carcinoma. Proc Natl Acad Sci USA 95: 6870-6875, 1998.
28. Curia MC, Palmirotta R, Aceto G, Messerini L, Verì MC, Crognale S, Valanzano R, Ficari F, Fracasso P, Stigliano V, et al: Unbalanced germ-line expression of hMLH1 and hMSH2 alleles in hereditary nonpolyposis colorectal cancer. Cancer Res 59: 3570-3575, 1999.

29. Debniak T, Kurzawski G, Gorski B, Kladny J, Domagala W and Lubinski J: Value of pedigree/clinical data, immunohistochemistry and microsatellite instability analyses in reducing the cost of determining hMLH1 and hMSH2 gene mutations in patients with colorectal cancer. Eur J Cancer 36: 49-54, 2000.

30. Ali AY, Farrand L, Kim JY, Byun S, Suh JY, Lee HJ and Tsang BK: Molecular determinants of ovarian cancer chemoresistance: New insights into an old conundrum. Ann N Y Acad Sci 1271: 58-67, 2012.

31. Thibault B, Castells M, Delord JP and Couderc B: Ovarian cancer microenvironment: Implications for cancer dissemination and chemoresistance acquisition. Cancer Metastasis Rev 33: 17-39, 2014

32. Li M, Yin J, Mao N and Pan L: Upregulation of phosphorylated cofilin 1 correlates with taxol resistance in human ovarian cancer in vitro and in vivo. Oncol Rep 29: 58-66, 2013.

33. Mok SC, Bonome T, Vathipadiekal V, Bell A, Johnson ME, Wong KK, Park DC, Hao K, Yip DK, Donninger H, et al: A gene signature predictive for outcome in advanced ovarian cancer identifies a survival factor: Microfibril-associated glycoprotein 2 . Cancer Cell 16: 521-532, 2009.

34. Fullwood P, Marchini S, Rader JS, Martinez A, Macartney D, Broggini M, Morelli C, Barbanti-Brodano G, Maher ER and Latif F: Detailed genetic and physical mapping of tumor suppressor loci on chromosome $3 \mathrm{p}$ in ovarian cancer. Cancer Res 59: 4662-4667, 1999.

35. Chng HW, Camplejohn RS, Stone MG, Hart IR and Nicholson LJ: A new role for the anti-apoptotic gene A20 in angiogenesis. Exp Cell Res 312: 2897-2907, 2006

36. Shridhar V, Staub J, Huntley B, Cliby W, Jenkins R, Pass HI, Hartmann L and Smith DI: A novel region of deletion on chromosome $6 \mathrm{q} 23.3$ spanning less than $500 \mathrm{~Kb}$ in high grade invasive epithelial ovarian cancer. Oncogene 18: 3913-3918, 1999.

37. Shayesteh L, Lu Y, Kuo WL, Baldocchi R, Godfrey T, Collins C, Pinkel D, Powell B, Mills GB and Gray JW: PIK3CA is implicated as an oncogene in ovarian cancer. Nat Genet 21: 99-102, 1999.

38. Cheaib B, Auguste A and Leary A: The PI3K/Akt/mTOR pathway in ovarian cancer: Therapeutic opportunities and challenges. Chin J Cancer 34: 4-16, 2015.

39. Friedlander ML, Russell K, Millis S, Gatalica Z, Bender R and Voss A: Molecular profiling of clear cell ovarian cancers: Identifying potential treatment targets for clinical trials. Int J Gynecol Cancer 26: 648-654, 2016. 